\title{
Kajian Persentase Ruang Terbuka Hijau pada Implementasi Revitalisasi Taman Kota Malang
}

\author{
Juwito Respati Wikantiyoso Pindo Tutuko \\ Mahasiswa Program Studi Magister Arsitektur Pascasarjana Universitas Merdeka Malang \\ Dosen Program Studi Magister Arsitektur Pascasarjana Universitas Merdeka Malang \\ Dosen Program Studi Magister Arsitektur Pascasarjana Universitas Merdeka Malang \\ Email: vernakular_konsultan2@yahoo.co.id
}

\begin{tabular}{|c|c|}
\hline & Abstract \\
\hline $\begin{array}{l}\text { Keywords: } \\
\text { Implementation; } \\
\text { Percentage; Revital- } \\
\text { ization; Green open } \\
\text { space }\end{array}$ & $\begin{array}{l}\text { The "Park Revitalization" program initiated by the Malang City Government with the private } \\
\text { sector is being implemented and the implementation of this program raises questions, namely the } \\
\text { extent to which this physical intervention should be carried out, so that integration and } \\
\text { sustainability have a positive impact, without reducing the existing green open space. This study } \\
\text { uses a quantitative methodology in the form of a Green Open Revitalization program review } \\
\text { conducted in Malang City by assessing the percentage reduction in area. Operational definitions } \\
\text { of variables used in this research design are in the form of transfer functions or building additions } \\
\text { and the use offunctional areas / materials or cover material. Analysis of the condition of objects by } \\
\text { referring to Area Revitalization. Objects of observation are analyzed using thematic maps and } \\
\text { statistical analysis. The results of the study show that there is a close correlation between the } \\
\text { conversion of functions or the addition of buildings and the use of functional areas / material or } \\
\text { cover material to the percentage of RTH. The selection of the right material with the theme and } \\
\text { characteristics of green open space with sustainable technology is an integrated entity with con- } \\
\text { tinuous improvement in the quality and quantity of the environment. }\end{array}$ \\
\hline
\end{tabular}

\section{Abstrak}

Kata-kunci: Implementasi; Persentase; Revitalisasi; $\mathrm{RTH}$

\begin{abstract}
Program "Revitalisasi Taman" yang digagas Pemerintah Kota Malang dengan pihak swasta sedang dilaksanakan dan implementasi program ini menimbulkan pertanyaan, yaitu sejauh mana intervensi fisik ini seyogyanya dilakukan, sehingga keterpaduan dan keberlanjutan berdampak positif, tanpa mengurangi luasan Ruang Terbuka Hijau (RTH) yang ada. Penelitian ini menggunakan Metodologi kuantitatif berupa review program Revitalisasi RTH yang dilaksanakan di Kota Malang dengan mengkaji seberapa besar persentase pengurangan luasannya. Definisi operasional variabel yang dipakai dalam rancangan penelitian ini berupa Alih fungsi atau penambahan bangunan dan Penggunaan area fungsional/bahan atau material penutup (cover). Analisis kondisi obyek dengan berpedoman Revitalisasi Kawasan. Obyek amatan dianalisis menggunakan petapeta tematik dan analisis statistik. Hasil penelitian menunjukkan bahwa terdapat korelasi erat antara alih fungsi atau penambahan bangunan dan penggunaan area fungsional/ bahan atau material penutup (cover) terhadap persentase RTH-nya. Pemilihan material yang tepat dengan tema dan ciri RTH dengan teknologi yang berkesinambungan menjadi satu kesatuan yang terintegrasi dengan perbaikan kualitas dan kuantitas lingkungan secara lestari.
\end{abstract}




\section{Kajian Persentase Ruang Terbuka Hijau pada Implementasi Revitalisasi Taman Kota Malang}

Juwito, Respati Wikantiyoso, Pindo Tutuko

\section{Pendahuluan}

Pembangunan wilayah perkotaan dengan memasukkan unsur lingkungan sebagai bagian dasar pertimbangan dalam pembangunan sumber daya alam dan lingkungan hidup, selaras dengan strategi Sustainable Development Goals (SDGs) (Sudarwani, 2015). Dampak dari penurunan kuantitas dan kualitas Ruang Terbuka Hijau (RTH) keberbagai sendi kehidupan perkotaan diantaranya terjadiya banjir, peningkatan pencemaran udara, dan menurunya produktifitas masyarakat akibat terbatasnya ruang yang tersedia untuk interaksi sosial (PERMENPU No.05, 2008).

Selaras dengan hal tersebut, PERMENDAGRI No.01 (2007) menyebutkan bahwa pertumbuhan dan perkembangan kawasan perkotaan disertai alih fungsi lahan yang pesat, telah menimbulkan kerusakan lingkungan yang dapat menurunkan daya dukung lahan dalam menopang kehidupan, sehingga diperlukan upaya untuk melestarikan, menjaga dan meningkatkan kualitas serta kuantitas lingkungan, melalui penyedian RTH yang memadai.

Dalam mengantisipasi Global Warming keputusan perancangan berkesinambungan mutlak dilakukan dalam proses Perencanaan dan perancangan perkotaan sebagai bentuk intervensi fisiknya. Keseimbangan pembangunan lingkungan fisik dan pelestarian lingkungan harus dilakukan untuk mewujudkan lingkungan perkotaan yang sehat bagi generasi yang akan datang. Keseimbangan antara RTH dan ruang yang dikembangkan dengan sistem infrastruktur hijau yang terintegrasi akan meningkatkan daya dukung lingkungan perkotaan (Wikantiyoso \& Tutuko, 2013).

Demikian juga yang terjadi di kota Lokoja-Nigeria berdasarkan Alabi (2009), Kenaikan populasi yang cepat, seiring dengan meningkatnya laju urbanisasi, telah menyebabkan perluasan kota Lokoja yang tidak terencana dan tidak terkendali, hal ini juga mengakibatkan hilangnya ruang terbuka secara bertahap di kota ini, sehingga diperlukanya upaya revitalisasi ruang terbuka hijau kota. Selaras dengan hal tersebut Rawung (2015), memaparkan bahwa pembangunan kawasan perkotaan yang parsial dan tidak berkesinambungan, secara fisik cenderung menghabiskan RTH yang berkontribusi menjadikanya area terbangun.

Berdasarkan Undang-Undang No.26 tentang Penataan Ruang Pasal 17 Ayat 5 Tahun 2007 secara tegas mengamanatkan 30\% dari wilayah kota berwujud RTH, 20\% RTH publik dan 10\% RTH privat (Undang-Undang No 26, 2007). Pengalokasian 30\% RTH ini ditetapkan dalam Peraturan Daerah (Perda) tentang RTRW Kota dan RTRW Kabupaten.

Di dalam aplikasinya munculah konsep 8 Atribut kota hijau yang salah satunya, yaitu poin No.3 Ketersediaan Ruang Terbuka Hijau (Green Open Space) (KEMENPUPERA, 2016). Atribut tersebut untuk menanggulangi permasalahan lingkungan dan pemanasan global yang berimplikasi terhadap permasalahan penataan kota. Hal tersebut senada dengan Sudarwani (2015), perlunya dirumuskan kebijakan serta program pengelolaan dan pengembangan RTH untuk meningkatkan kualitas hidup perkotaan.

Program “Revitalisasi Taman” yang digagas pemerintah kota Malang dengan pihak swasta sedang dilaksanakan. Dari hasil kerjasama ini menghasilkan obyek RTH (Taman dan Hutan Kota yang terkonsep), serta masing-masing obyek memiliki beragam tema dan karakteristiknya.

Dari implementasi program ini menimbulkan pertanyaan, sejauh mana intervensi fisik seyogyanya dilakukan, sehingga keterpaduan dan keberlanjutan berdampak positif, tanpa mengurangi luasan RTH yang ada. Dapatkah dicapai RTH yang ideal sesuai dengan tujuan program revitalisasi? 
LOCAL WISDOM, Vol. 11 No. 1 Januari 2019

Local Wisdom Scientific Online Journal

\section{Kajian Pustaka}

\section{Definisi dan Fungsi RTH}

Definisi RTH berdasarkan PERMENPU No.05, (2008) RTH adalah area memanjang/jalur dan/ atau mengelompok, yang penggunaannya lebih bersifat terbuka, tempat tumbuh tanaman, baik yang tumbuh secara alamiah maupun yang sengaja ditanam.

Menurut Wikantiyoso (2010), RTH Kawasan perkotaan merupakan bagian dari ruang perkotaan guna mendukung manfaat langsung atau tidak langsung yang diisi oleh tumbuhan, tanaman dan vegetasi. Bentuk RTH dapat diklasifikasi menjadi (1) RTH non alami atau RTH binaan (pertanian kota, pertamanan kota, lapangan olah raga, pemakaman; dan (2) RTH alami (habitat liar/alami, kawasan lindung).

Berdasarkan sifat dan karakter ekologisnya, bentuk RTH dapat diklasifikasikan menjadi (1) RTH jalur (koridor, linear); dan (2) RTH kawasan (areal, non linear). Sedangkan berdasarkan penggunaan lahan atau kawasan fungsionalnya diklasifikasi menjadi (1) RTH kawasan permukiman; (2) RTH kawasan perdagangan; (3) RTH kawasan perindustrian; (4) RTH kawasan pertanian; dan (5) RTH kawasankawasan khusus, seperti pemakaman, hankam, olah raga, alamiah (Wikantiyoso, 2010).

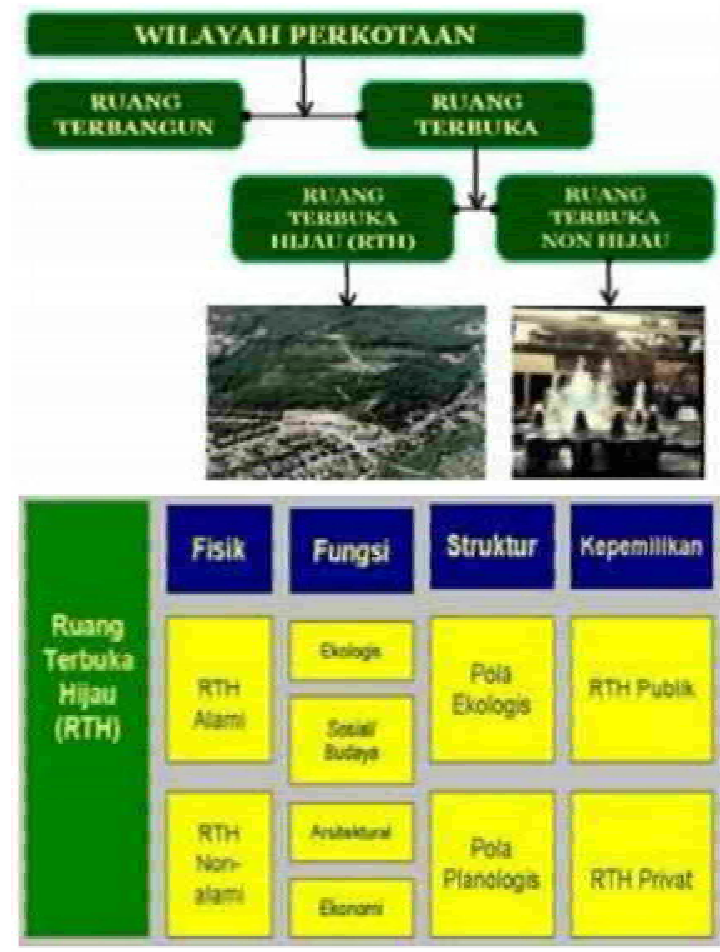

Tabel 1 Kedudukan RTH secara Fisik, Fungsi, Struktur dan Kepemilikan dalam wilayah perkotaan Sumber: (Ekaputra YD, 2012)

Menurut UU No.26, (2007) RTH dapat dibedakan berdasar status kepemilikan RTH menjadi (1) RTH privat atau non publik, yaitu RTH yang berlokasi pada lahan-lahan milik privat; dan (2) RTH publik, yaitu RTH yang berlokasi pada lahan-lahan publik atau lahan yang dimiliki oleh pemerintah (pusat, daerah). RTH, baik RTH 
publik maupun RTH privat, memiliki fungsi utama yaitu fungsi ekologis, dan fungsi tambahan yaitu fungsi arsitektural, sosial, dan fungsi ekonomi. Fungsi ekologis RTH yang baik akan menjamin keberlanjutan suatu wilayah perkotaan. Fungsi-fungsi RTH lainnya (sosial, ekonomi, arsitektural) merupakan fungsi pendukung dan penambah nilai kualitas lingkungan dan budaya kota. Dalam suatu wilayah perkotaan 4 (empat) fungsi utama ini dapat dikombinasikan sesuai dengan kebutuhan, kepentingan, dan keberlanjutan kota. (Wikantiyoso, 2017).

\section{Material Penutup (Ground Cover) RTH}

Terdapat beberapa macam bahan yang digunakan sebagai material penutup ground Cover pada RTH. Pemilihan bahan yang tepat dalam proses perencanaan dan pelaksanaan merupakan aspek yang vital. Hal ini ditengarahi akan mempengaruhi aspek fungsi dan kulitas RTH secara langsung. berikut material penutup tersebut diantaranya:

1. Full Hard Space

a. Aspal ialah bahan hidro karbon yang bersifat melekat (adhesive), berwarna hitam kecoklatan, tahan terhadap air, dan visoelastis. Aspal sering juga disebut bitumen merupakan bahan pengikat pada campuran beraspal yang dimanfaatkan sebagai lapis permukaan lapis perkerasan lentur (PERMEN PU No.12, 2009)

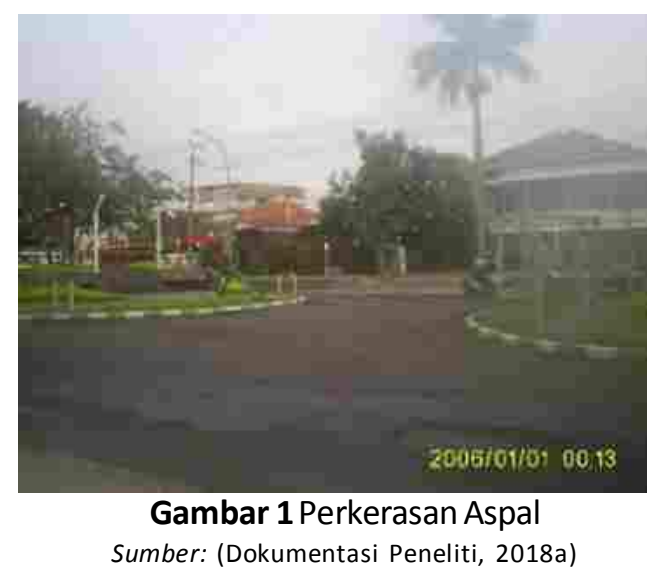

b. Plesteran Beton Cor ditempat (cast-in place) adalah beton yang di cor di lokasi pekerjaan (PERMEN PU No.12, 2009).

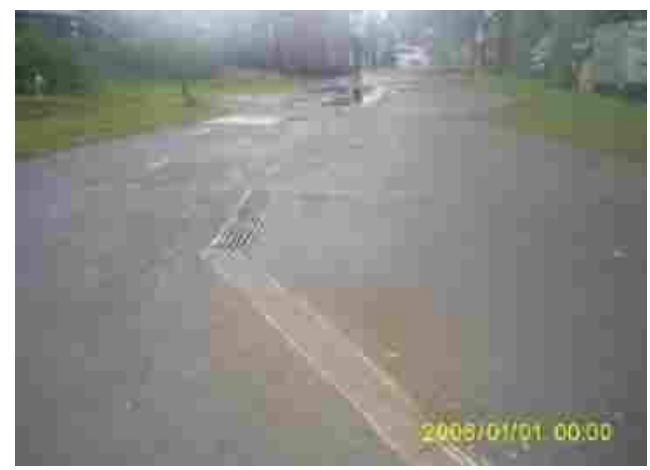

Gambar 2 Plesteran Beton Cor

Sumber: (Dokumentasi Peneliti, 2018b) 
2. Semi Hard Space

a. Paving block adalah material perkerasan pracetak berbentuk seperti batu bata. jenis bahan atau material yang digunakan untuk menutup permukaan tanah secara buatan yang bersifat keras (tidak lunak) (PERMEN PU No.12, 2009).

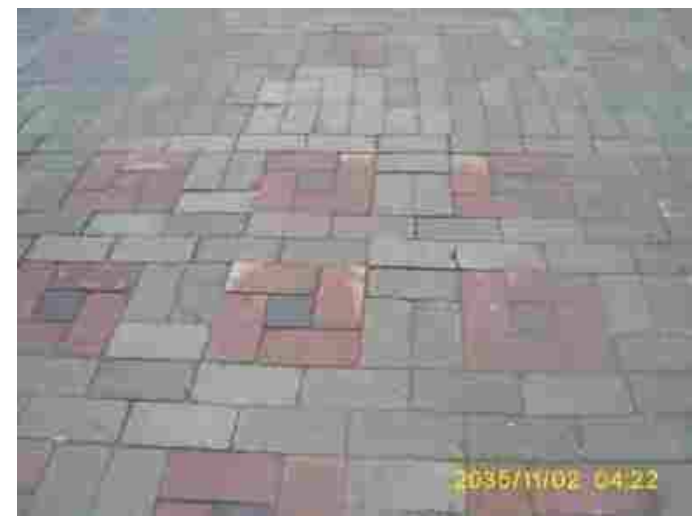

Gambar 3 Paving Block

Sumber: (Dokumentasi Peneliti, 2018c)

b. Grass Block adalah bahan bangunan untuk perkerasan jalan, area parkir, taman, dan sebagainya. Hampir sama fungsinya dengan Paving Block. Hanya bedanya, ia memiliki rongga yang dapat ditanami rumput (PERMEN PU No.12, 2009).

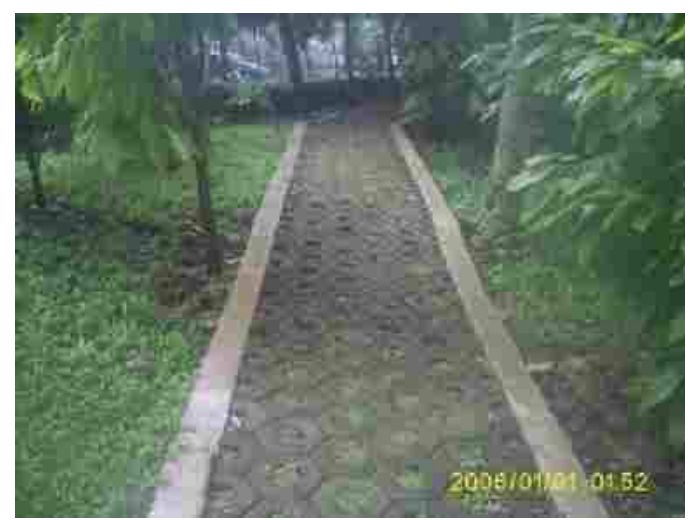

Gambar 4 Grass Block

Sumber: (Dokumentasi Peneliti, 2018d)

c. Beton berpori (porous concrete) adalah tipe perkerasan LID permiable pavement,yaitu campuran beton berpori yang tidak menggunakan pasir atau hanya dalamjumlah kecil, sehingga menghasilkan beton dengan pori kira-kira $20 \%$. Ruang pori tersebut membuat air dapat mengalir didalam perkerasan ke lapisan batuanberukuran seragam dibawahnya, lalu kedalam tanah sehingga mengurangi ataumenghilangkan aliran air di atas permukaan perkerasan. Kekuatan rata-rata daribeton berpori (tembus air) adalah dari 50 sampai $350 \mathrm{~kg} / \mathrm{cm} 2$, dan dapat lebih tinggi tergantung fungsi penggunaannya. Kecepatan peresapan adalah 0,2 sampai 0,48cm/s (PERMEN PU No.12, 2009). 


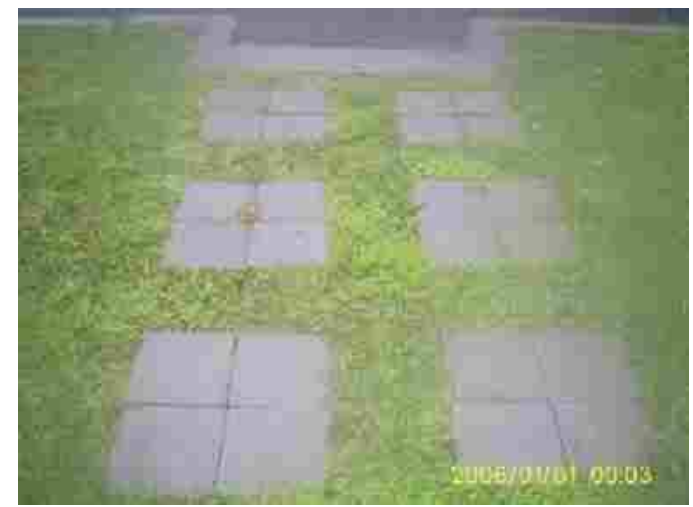

Gambar 5 Beton Berpori

Sumber: (Dokumentasi Peneliti, 2018e)

d. Perkerasan permeable (permeable paving) adalah tipe LID yaitu perkerasan tembus air atau perkerasan poros yaitu jenis perkerasan yang berpori sehingga dapat mengalirkan air di permukaan perkerasan ke lapisan dibawahnya (PERMEN PU No.12, 2009).

3. Soft Space

a. Tanah adalah bagian kerak bumi yang tersusun dari mineral dan bahan organik

b. Rumput adalah tumbuhan monokotil yang memiliki daun berbentuk sempit meruncing yang tumbuh dari dasar batang (PERMEN PU No.12, 2009).

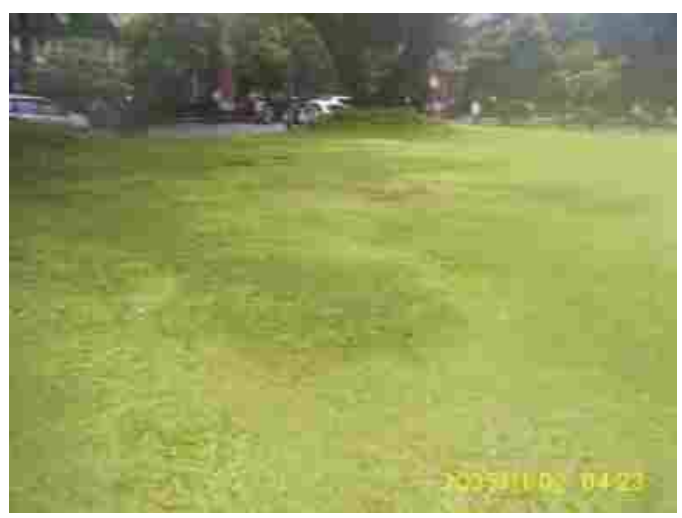

Gambar 6 Rumput

Sumber: (Dokumentasi Peneliti, 2018f)

c. Semak alami (bio-swales) adalah area dengan tumbuhan seperti area rerumputan dan tanaman pendek (PERMEN PU No.12, 2009). 


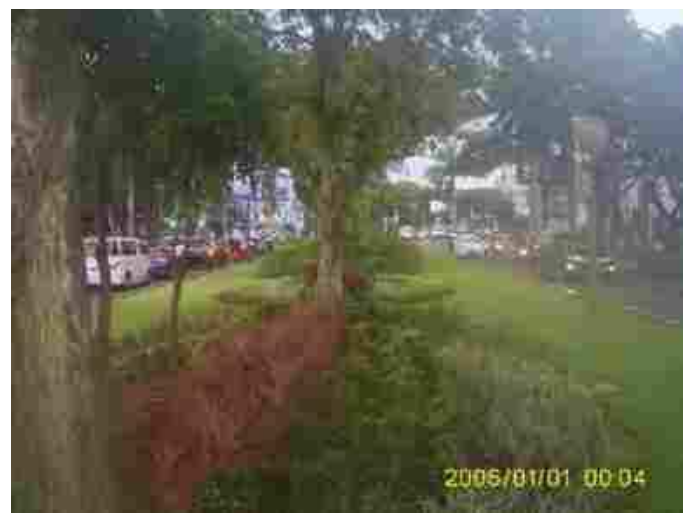

Gambar 7Semak

Sumber: (Dokumentasi Peneliti, 2018g)

d. Sel bio-retensi (bioretention cells) adalah tipe LID berupa campuran tanah dengan kelembaban di atas lapisan batu beserta tanaman yang tahan terhadap kondisi basah dan kering yang berfungsi menampung dan mengalirkan air resapan ke lapisan dibawahnya selama 24 jam yang merupakan masukan untuk air tanah dan tidak memberi kesempatan terjadi genangan dan kemungkinan berkembang biaknya nyamuk. Digunakan pada pulau pada area parkir, tepi dari area perkerasan, disisi-sisi bangunan, jalur median, ruang terbuka dan area rerumputan (PERMEN PU No.12, 2009).

e. Vegetasi/tumbuhan adalah keseluruhan tetumbuhan dari suatu kawasan baik yang berasal dari kawasan itu atau didatangkan dari luar, meliputi pohon, perdu, semak, dan rumput (PERMEN PU No.12, 2009).

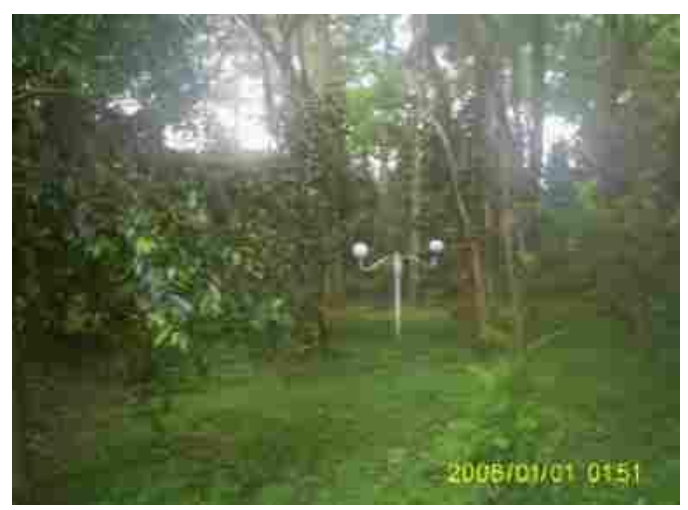

Gambar 8 Vegetasi/Tumbuhan

Sumber: (Dokumentasi Peneliti, 2018h)

\section{Revitalisasi}

Definisi Revitalisasi berdasarkan Permen PU No.18 (2011) tentang Pedoman Revitalisasi Kawasan adalah upaya untuk meningkatkan nilai lahan/kawasan melalui pembangunan kembali dalam suatu kawasan yang dapat meningkatkan fungsi kawasan sebelumnya (BIROHUKUM, 2011). 
Senada hal tersebut makna revitalisasi berdasarkan Wikantiyoso (2005), adalah suatu upaya mem"vitalkan" kembali atau meningkatkan kualitas dan kuantitas (aktivitas, nilai estetika/visual arsitektur) suatu kawasan sesuai dengan konteks perencanaan dan perancangan kawasan tertentu, sehingga kawasan tersebut mempunyai "daya hidup". Revitalisasi Kawasan merupakan rangkaian upaya menghidupkan kembali kawasan yang mengalami penurunan kualitas fisik dan non fisik, meningkatkan nilai-nilai vitalitas yang strategis dan signifikansi dari kawasan yang mempunyai potensi dan/atau mengendalikan kawasan yang cenderung tidak teratur, untuk mengembalikan atau menghidupkan kembali kawasan dalam ikatan kota sehingga berdampak pada kualitas hidup warganya, melalui peningkatan kualitas lingkungan kawasan.

Berdasarkan PERMENPU No.18 (2011) menerangkan bahwa sebuah kegiatan yang sangat kompleks, proses-proses revitalisasi terjadi melalui beberapa tahapan. Tahapan ini membutuhkan kurun waktu tertentu serta meliputi hal - hal sebagai berikut diantaranya adalah:

1. Intervensi fisik

Intervensi fisik ini perlu dilakukan mengingat citra kawasan sangat erat kaitannya dengan kondisi visual kawasan khususnya dalam menarik kegiatan pengunjung. Mengawali kegiatan fisik revitalisasi dilakukan intervensi fisik secara bertahap, meliputi perbaikan dan peningkatan kualitas dan kondisi fisik bangunan, tata hijau, sistem penghubung, system tanda/reklame dan ruang terbuka kawasan (urban realm).

Intervensi fisik pun sudah semestinya memperhatikan konteks lingkungan sehingga isu lingkungan (environmental sustainability) pun menjadi penting, Perencanaan fisik tetap harus dilandasi pemikiran jangka panjang, komprehensif, berkesinambungan dan lestari.

2. Rehabilitasi ekonomi

Upaya memberikan nilai tambah bagi kawasan kota merupakan salah satu tujuan upaya rehabilitasi ekonomi. Perbaikan fisik kawasan yang bersifat jangka pendek, diharapkan bisa mengakomodasi kegiatan ekonomi informal dan formal (local economic development).

Proses rehabilitasi kegiatan ekonomi yang diawali dengan proses peremajaan artefak urban harus mendukung proses revitalisasi. Perlu dikembangkan fungsi campuran yang bisa mendorong terjadinya aktivitas ekonomi dan sosial (vitalitas baru). dalam konteks revitalisasi.

3. Revitalisasi sosial/institusional

Revitalisasi sosial/intitusional dapat diawali dengan menciptakan lingkungan yang menarik (interesting) dengan didukung oleh suatu pengembangan institusi yang baik. Hal ini merupakan parameter revitalisasi sebuah kawasan jadi bukan sekedar membuat beautiful place. Kegiatan tersebut harus dapat meningkatkan dinamika dan kehidupan sosial masyarakat/warga (public realms). dan memberikan dampak positif pada kegiatan perancangan dan pembangunan kota untuk menciptakan lingkungan sosial yang berjati diri (place making) (BIROHUKUM, 2011).

\section{Permasalahan}

Penelitian ini didasari oleh sulitnya afordibilitas Pemerintah Kota Malang dalam mewujudkan RTH Kota yang ideal (UU No.26, Pasal 17 Ayat 5 2007). Dengan luas mencapai 110,06 km, kota Malang baru dapat mengalokasikan RTH sebesar 18,14\% yang diperuntukkan sebagai RTH (Wikantiyoso, 2017). 
Masih menyisakan 11,86\% untuk dapat mewujudkan amanah Undang-undang tersebut. serta berkurangnya sedikit demi sedikit volume RTH Kota yang sudah terbatas dengan pelaksanaan program tersebut. Dari uraian latar belakang tersebut maka permasalahan penelitian ini adalah:

1. Bagaimanakah perubahan kuantitas ruang setelah pelaksanaan program Revitalisasi RTH Kota Malang?

2. Faktor-faktor apakah yang menyebabkan perubahan kuantitas ruang setelah pelaksanaan program Revitalisasi RTH Kota Malang?

\section{Tujuan Penulisan}

Berdasarkan perumusan masalah tersebut diatas maka penelitian ini secara khusus bertujuan untuk:

1. Menghitung, mengevaluasi dan menganalisis perubahan kuantitas ruang setelah pelaksanaan program revitalisasi RTH Kota Malang.

2. Menghitung, mengevaluasi dan menganalisis faktor-faktor yang menyebabkan perubahan kuantitas ruang setelah pelaksanaan program revitalisasi RTH Kota Malang.

\section{Batasan Penulisan}

Batasan Penelitian ini memfokuskan pada obyek amatan RTH Taman dan Hutan Kota Malang yang representatif (kualitas lingkungan dan public space). Kajian ini di estimasikan mewakili 4 (empat) type obyek RTH yang ada yaitu RTH Publik berupa RTH Alami (Hutan kota Malabar) dan RTH Non alami buatan/binaan (Alun-alun Merdeka), dan ruang koridor atau pergerakan linier berupa jalur hijau jalan (Koridor Jalan dan Pedestrian Dieng) dan Ruang pulau atau oasis sebagai tempat pemberhentian / istirahat (Taman Slamet).

\section{Metodologi}

Metodologi penelitian pada obyek kajian ini menggunakan metode kuantitatif. Metode ini berupa review program Revitalisasi RTH yang dilaksanakan di Kota Malang. Review ini dengan mengkaji seberapa besar perubahan kuantitas ruangnya. Dengan kata lain evaluasi pelaksanaan program dengan melakukan pengukuran dengan analisis berbasis peta rencana dengan kondisi yang ada. Pengurangan secara kualitatif walaupun tidak mengabaikan faktor pengaruhnya (pengukuran).

Definisi operasional variabel yang dipakai dalam rancangan penelitian ini berupa (1) Alih fungsi atau penambahan bangunan dan; (2) Penggunaan area fungsional/bahan atau material penutup (cover). Pengurangan RTH ini secara fungsional berupa bahan (1) Soft Space dan; (2) Hard Space. Selanjutnya menghitung Coverage dalam bentuk hard space yaitu (1) Full hard space; (2) Semi hard space; (3) Soft space.

Data primer untuk penelitian ini, terdiri dari: (1) Analisis Kondisi Kekinian Objek; Dokumen Perencanaan dan Perancangan Teknis, DED, Soft Drawing Dan As Build Drawing (Obyek program), Hasil Akhir Pelaksanaan Konstruksi Lapangan; (2) Foto Udara; (3) Peta-peta tematik (land use); (4) Monogram; (5) Luas RTNH; (6) RTRH;RTRW; (7) RPJMD; (8) Pengukuran Lapangan; (9) sebaran Quisioner untuk respondensi. 


\section{Pengumpulan Data}

Metode pengumpulan data dengan melakukan pengukuran pada ke 4 (empat) objek penelitian, menganalisa Dokumen Perencanaan Dan Perancangan Teknis, DED, Soft Drawing dan As Buid Drawing (Obyek Kajian), Hasil Akhir Pelaksanaan Konstruksi Lapangan, foto udara, peta tematik, data statistik, observasi lapangan dan sebaran Quisioner untuk respondensi. Obyek yang terdapat dalam peta-peta tematik dan data statistik didelinasi menggunakan sofware Auto Cad 2010, sedangkan hasil quisioner respondensi di masukkan Microsoft Excell untuk selanjutnya diolah melalui program IBM SPSS Statistics 17.0. dengan metode analisa Croostabulation. Sampel ditentukan sebanyak 30 respondensi dengan asumsi 1 atau 2 respondensi dianggap tidak valid untuk masing-masing objek penelitian.

\section{Analisis Data}

Analisis Data obyek kajian secara kuantitatif yaitu melakukan review program dengan pengukuran objek penelitian, menganalisa Dokumen Perencanaan Dan Perancangan Teknis, DED, Soft Drawing dan As Buid Drawing (Obyek Kajian), Hasil Akhir Pelaksanaan Konstruksi Lapangan, foto udara, peta tematik, data statistik, observasi lapangan dan sebaran Quisioner untuk respondensi. Obyek yang terdapat dalam peta-peta tematik dan data statistik didelinasi menggunakan sofware Auto Cad 2010, sedangkan hasil quisioner respondensi di masukkan Microsoft Excell 2013 untuk selanjutnya diolah melalui program IBM SPSS Statistics 17.0. Hasil analisis yang diteliti berupa volume persentase pengurangan RTH.

\section{Analisis dan Interpretasi}

\section{Taman Alun-alun Merdeka Kota Malang}

Taman Alun-alun Merdeka Kota Malang terletak di Jalan Merdeka Selatan, yang biasa dikenal dengan alun-alun "kotak". Berada dalam wilayah Kauman Kelurahan Kidul Dalem Kecamatan Klojen Kota Malang. Alun-alun Merdeka merupakan RTH strategis berfungsi sebagai media penanda Kota. Simbol keselarasan hubungan dengan alam, seimbang dalam spirituil dan meteriil.

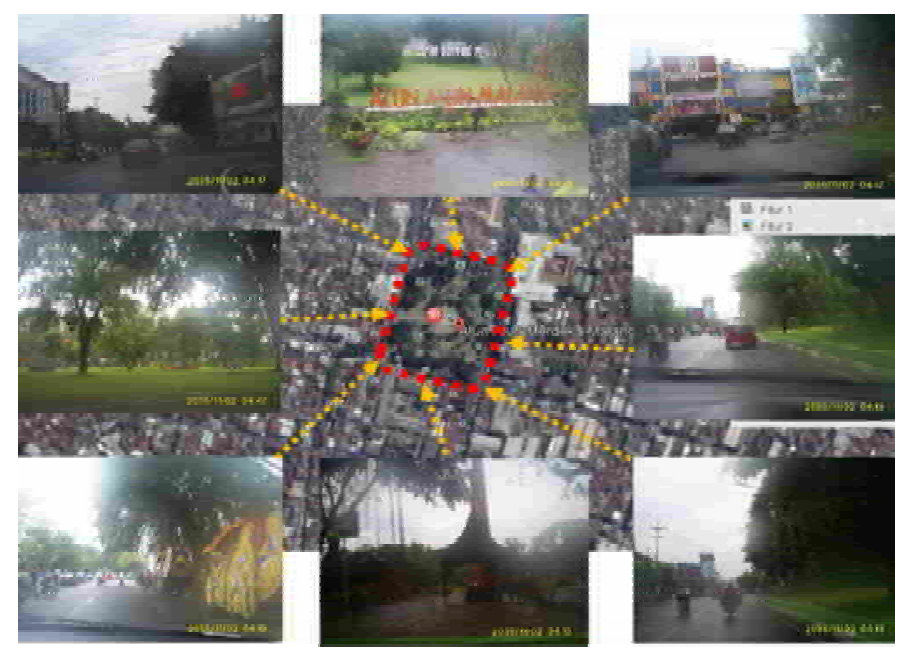

Gambar 9 V isualisasi Taman Alun-alun Merdeka Kota Malang Sumber: (Google Earth Pro, diakses Kamis,07/12/2017 jam 11.24 dan Dokumentasi Peneliti 2018) 
Berawal dari pengukuran lapangan pada ke 4 (empat) obyek kajian, selanjutnya data pengukuran dimasukkan kedalam program Auto cad 2010 dengan skala 1:1000. Pengurangan (coverage) pada full hard space, semi hard space dan soft space dipoliline-kan menjadi 3 (tiga) bagian. hasil poline tersebut diareakan 1 (satu) per (satu) sehingga muncullah nilai areanya masing-masing. dari total area lahan dipersentasikan berdasarkan ke3 (tiga) bagian poliline tersebut, dengan demikian muncullah persentasinya masing-masing dari ke 3 (tiga) objek kajian tersebut.

Sesuai dengan hasil observasi dan pengukuran dilapangan pada Taman Alun-alun Merdeka Malang, didapatkanlah perhitungan berdasarkan Tabel 6 berupa Full Hard Space 9\%, terdapat alih fungsi atau penambahan bangunan berupa pos polisi, Area Skateboard, Toilet, Rg.Duduk, Kolam Air Mancur, Gudang, Area Bermain Anak, Papan catur, Lampu Penerangan dengan material penutup Atap galvalume dan dak beton. Semi Hard Space 15\% dengan penambahan paving stone dengan material penutup beton, sedangkan Soft Space 76\% berupa hamparan rumput hijau dengan varietas rumput gajah mini.

Tabel 2 Kajian Persentase Alih Fungsi dan Material Penutup pada Taman Alun-alun Merdeka Kota Malang

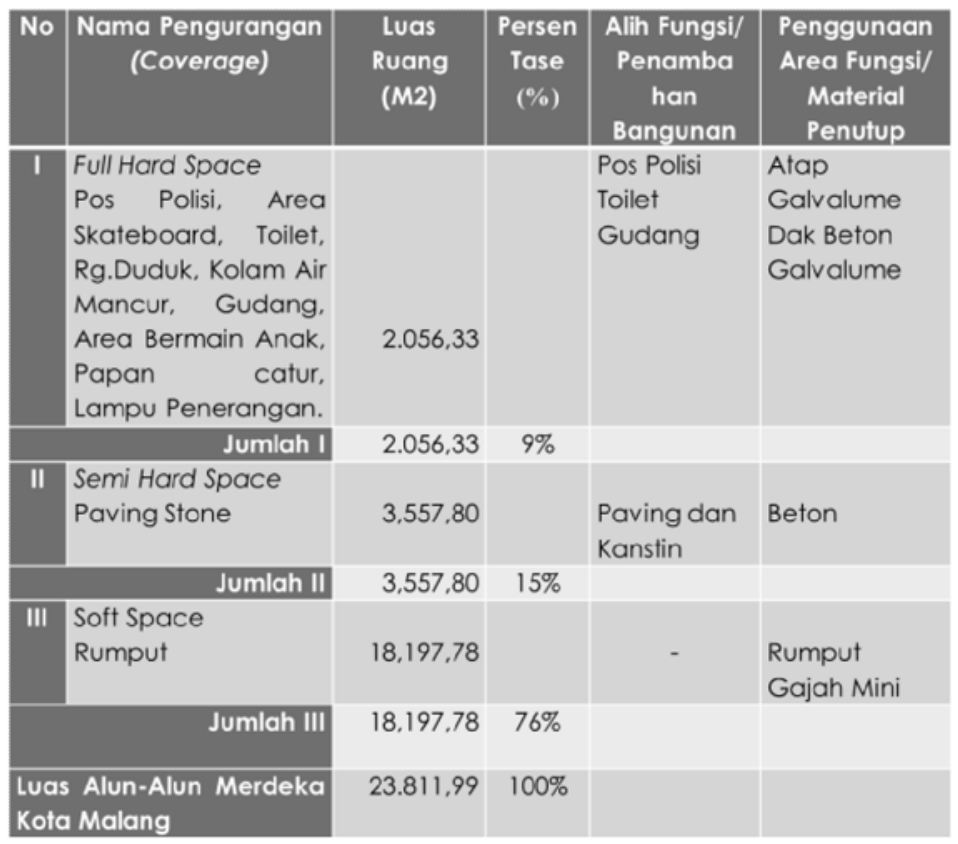

Sumber: Hasil Riset Peneliti (2018)

Hasil analisis Gambar 20 meperlihatkan material penutup (covering) pada Taman Alun-alun Merdeka Malang yang terdiri dari ; warna merah (hard space), warna kuning (semi hard space) dan warna hijau (sofe space). 


\section{Kajian Persentase Ruang Terbuka Hijau pada Implementasi Revitalisasi Taman Kota Malang}

Juwito, Respati Wikantiyoso, Pindo Tutuko

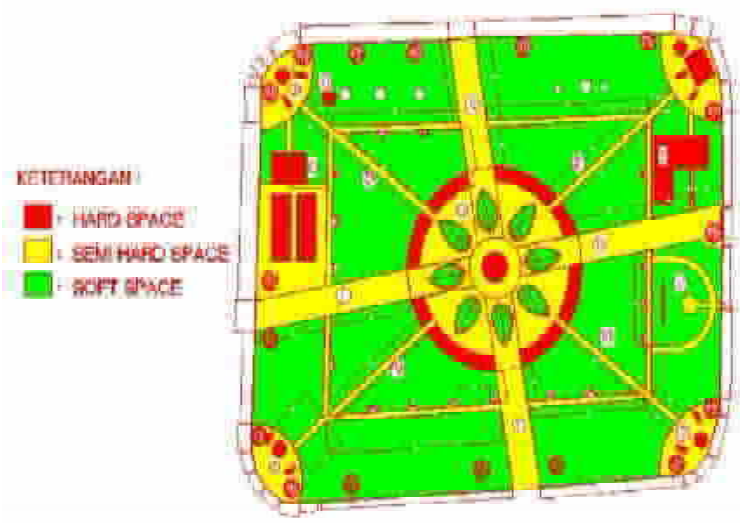

Gambar 10 Analisis Persentase Alih Fungsi dan Material Penutup pada Taman Alun-alun Merdeka Kota Malang

Skala 1:1000

Sumber: Hasil Riset Peneliti (2018)

Hasil analisis Pie Chart menunjukkan persentase material penutup (covering) pada Taman Alunalun Merdeka Malang yang terdiri dari; warna merah hard space $(9 \%)$, warna kuning semi hard space (15\%) dan warna hijau sofe space $(76 \%)$.

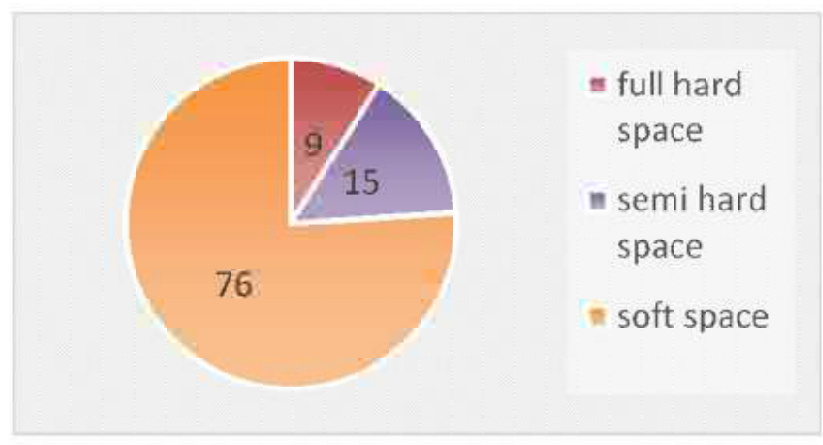

Pie Chart 1 Persentase Alih Fungsi dan Material Penutup pada Taman Alun-alun Merdeka Kota Malang Sumber: (Analisis Peneliti, 2018)

Proses-proses revitalisasi berdasarkan Permen PU No.18 (2011) tentang Pedoman Revitalisasi Kawasan terjadi melalui beberapa tahapan Revitalisasi yaitu (1) Intervensi Fisik; (2) Rehabilitasi Ekonomi; dan (3) Revitalisasi sosial/institusional. Tahapan ini selanjutnya akan dijadikan acuan untuk mendapatkan persentasi dari ke 4 (empat) abjek penelitian.

Dalam objek penelitian ini unsur, elemen, dan komponen revitalisasi didapatkan melalui observasi lapangan, pengukuran objek penelitian serta wawancara dan penyebaran Quisioner respondensi. Sampel ditentukan sebanyak 30 respondensi dengan asumsi 1 atau 2 respondensi dianggap tidak valid untuk masing-masing objek penelitian. Tabel 7 menunjukkan Ringkasan pengolahan data Respondensi yang diolah menggunakan Sofeware SPSS Statistics 17.0. dengan metode analisa Croostabulation. 
LOCAL WISDOM, Vol. 11 No. 1 Januari 2019

Local Wisdom Scientific Online Journal

Tabel 3 Kondisi sebelum, sesudah, temuan penelitian dan masukan penelitian

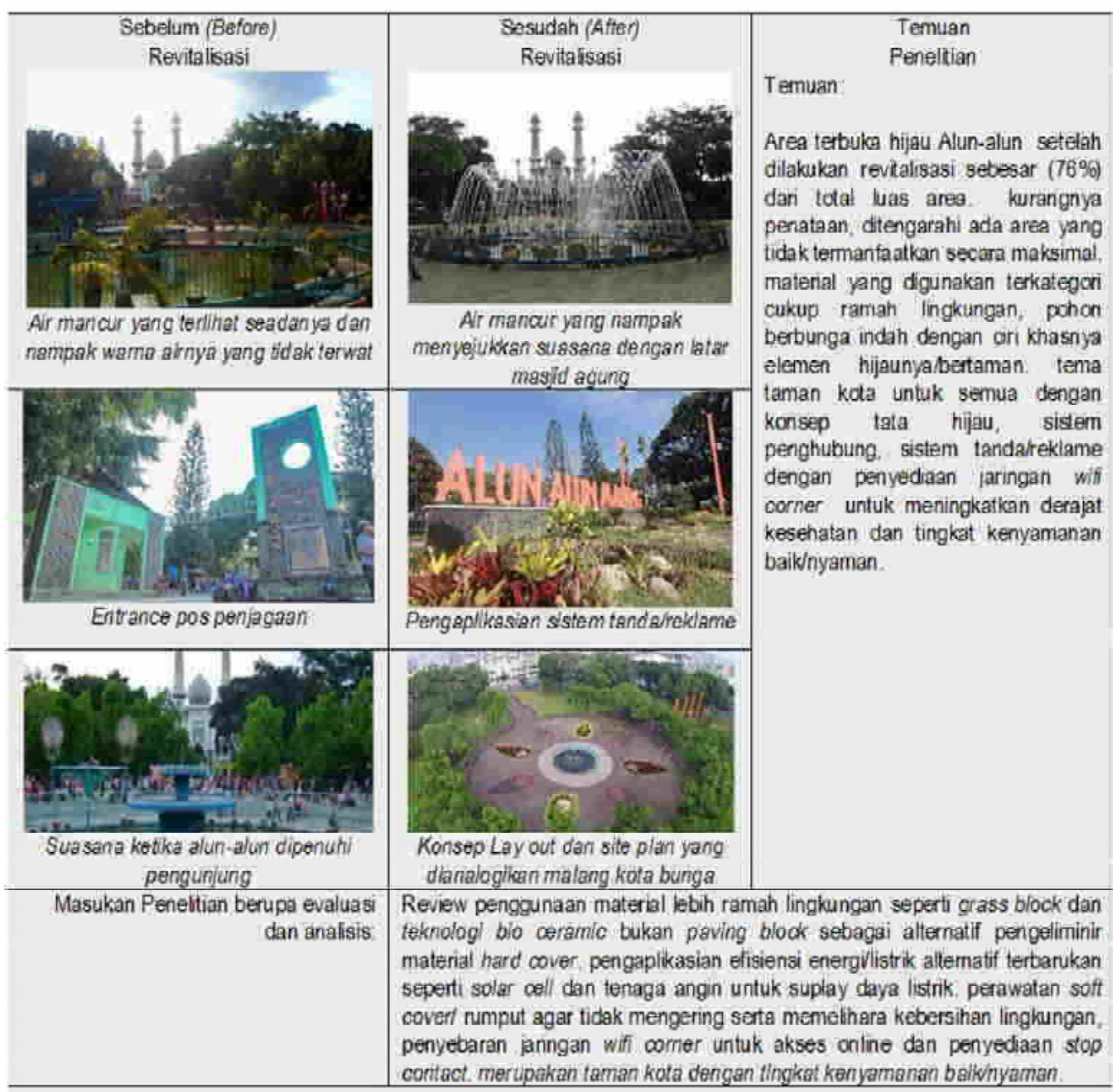

Sumber: Hasil Riset Peneliti (2018)

\section{Taman Slamet}

Taman Slamet terletak di Jalan Slamet Kelurahan Gading Kasri Kecamatan Klojen Kota Malang. Taman ini tergolong Ruang pulau atau tempat pemberhentian sementara. penggunaan RTH ini sebagai areal taman, sosialisasi, releksasi dan rekreasi dalam wilayah hirarki ketetanggaan dan komuniti sebagai taman aktif. 


\section{Kajian Persentase Ruang Terbuka Hijau pada Implementasi Revitalisasi Taman Kota Malang}

Juwito, Respati Wikantiyoso, Pindo Tutuko

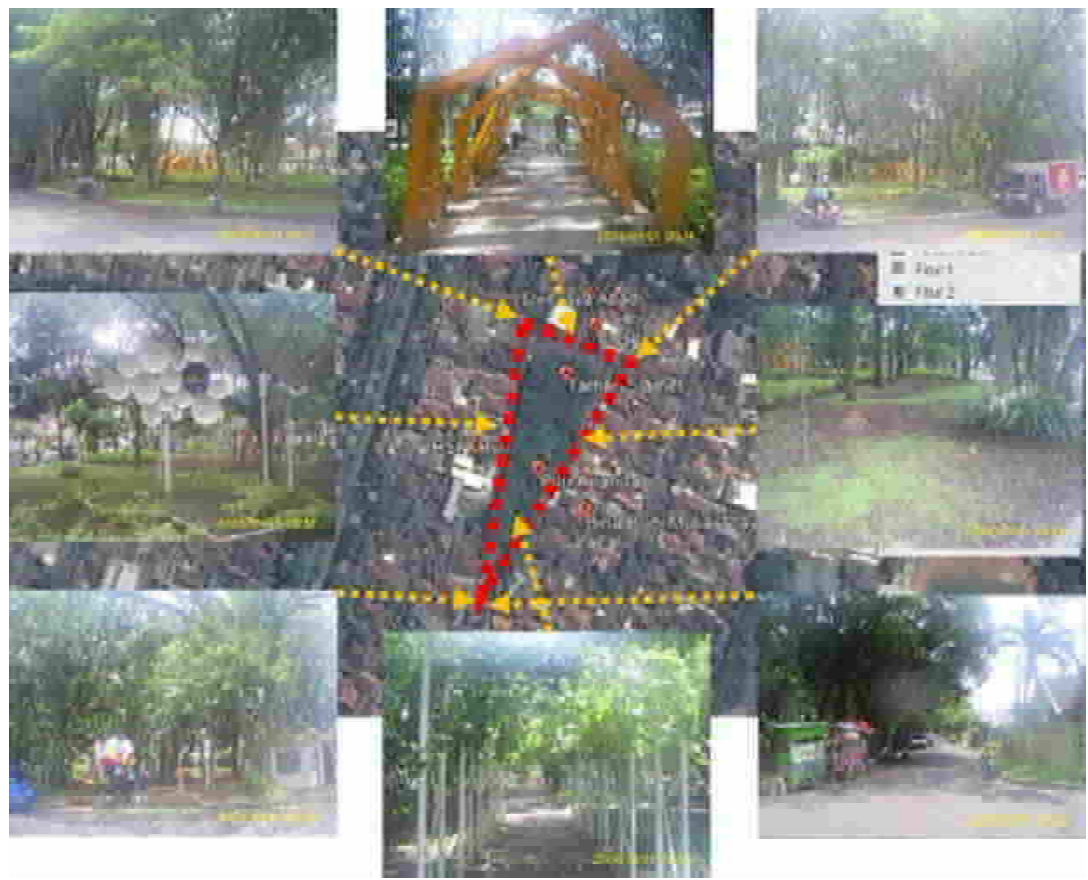

Gambar 11 Visualisasi Taman Slamet Kota Malang

Sumber: (Google Earth Pro, diakses Kamis,07/12/ 2017 jam 11.24 dan Dokumentasi Peneliti 2018i)

Sesuai dengan hasil observasi dan pengukuran dilapangan, didapatkanlah perhitungan berdasarkan Tabel 20 berupa Full Hard Space 4\%, terdapat alih fungsi atau penambahan bangunan berupa pos jaga, ruang duduk, plesteran serta lampu penerangan dengan material penutup Atap genteng (pos jaga).Semi Hard Space $50 \%$ dengan penambahan paving stone dan kanstin dengan material penutup beton, sedangkan Soft Space $46 \%$ berupa hamparan rumput hijau dengan varietas rumput gajah mini.

Tabel 4 Kajian Persentase Alih Fungsi dan Material Penutup pada Taman Slamet Kota Malang

\begin{tabular}{|c|c|c|c|c|c|}
\hline No & $\begin{array}{c}\text { Nama Pengurangan } \\
\text { (Coverage) }\end{array}$ & $\begin{array}{l}\text { Luas } \\
\text { Ruang } \\
\text { (M2) }\end{array}$ & $\begin{array}{c}\text { Persen } \\
\text { tase } \\
(\%)\end{array}$ & $\begin{array}{l}\text { Alih Fungsi/ } \\
\text { Penambahan } \\
\text { Bangunan }\end{array}$ & \begin{tabular}{|l} 
Penggunaan \\
Area Fungsil \\
Material \\
Penutup \\
\end{tabular} \\
\hline \multirow[t]{2}{*}{ I } & $\begin{array}{l}\text { Full Hard Space } \\
\text { Pos Jaga,R.Duduk dan } \\
\text { Plesteran, Lampu } \\
\text { Penerangan. }\end{array}$ & 204,09 & & $\begin{array}{l}\text { Pos Jaga } \\
\text { Plesteran }\end{array}$ & $\begin{array}{l}\text { Atap Genteng } \\
\text { Beton Aci }\end{array}$ \\
\hline & Jumlah I & 204,09 & $4 \%$ & & \\
\hline \multirow[t]{2}{*}{ II } & $\begin{array}{l}\text { Semi Hard Space } \\
\text { Paving Stone }\end{array}$ & $2.770,01$ & & $\begin{array}{l}\text { Paving dan } \\
\text { Kanstin }\end{array}$ & Beton \\
\hline & Jumlah II & $2.770,01$ & $50 \%$ & & \\
\hline \multirow[t]{2}{*}{ IIII } & $\begin{array}{l}\text { Soft Space } \\
\text { Rumput }\end{array}$ & $2.564,43$ & & - & $\begin{array}{l}\text { Rumput Gajah } \\
\text { Mini }\end{array}$ \\
\hline & Jumlah III & $2.564,43$ & $46 \%$ & & \\
\hline $\begin{array}{l}\text { Luas } \\
\text { Slam }\end{array}$ & $\begin{array}{l}\text { Keseluruhan Taman } \\
\text { net Kota Malang }\end{array}$ & $5.538,53$ & $100 \%$ & & \\
\hline
\end{tabular}

Sumber: Hasil Riset Peneliti (2018) 
Hasil analisis Gambar 23 meperlihatkan material penutup (covering) pada Taman Slamet Kota Malang yang terdiri dari; warna merah (hard space), warna kuning (semi hard space) dan warna hijau (sofe space).

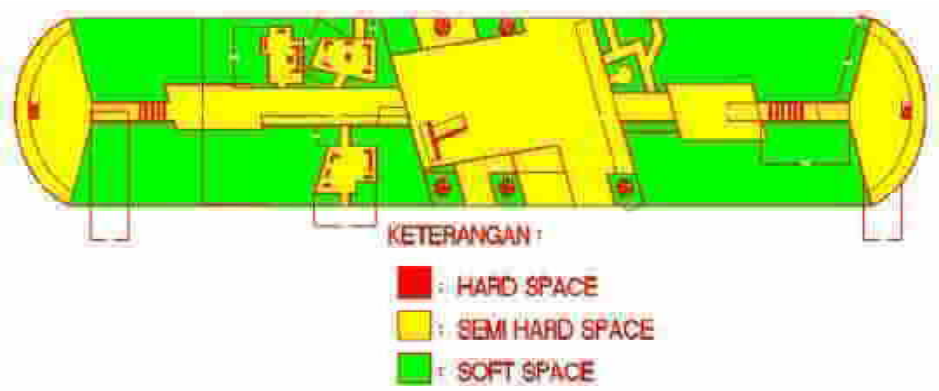

Gambar 12 Analisis Persentase Alih Fungsi dan Material Penutup pada Taman Alun-alun Merdeka Kota Malang Skala 1:1000

Sumber: Hasil Riset Peneliti (2018)

Hasil analisis Pie Chart menunjukkan persentase material penutup (covering) pada Taman Slamet Kota Malang yang terdiri dari; warna merah hard space (4\%), warna kuning semi hard space (50\%) dan warna hijau sofe space (46\%).

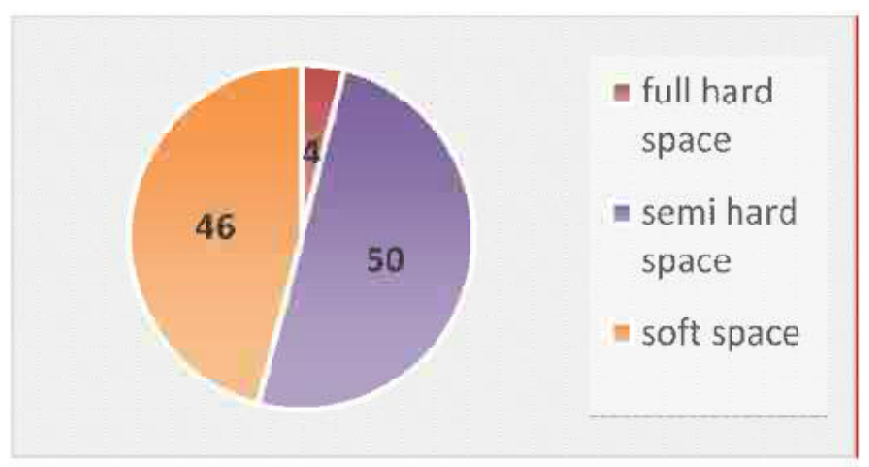

Pie Chart 2 Persentase Alih Fungsi dan Material Penutup pada Taman Slamet Kota Malang Sumber: (Analisis Peneliti, 2018) 
Tabel 5 Kondisi sebelum, sesudah, temuan penelitian dan masukan penelitian

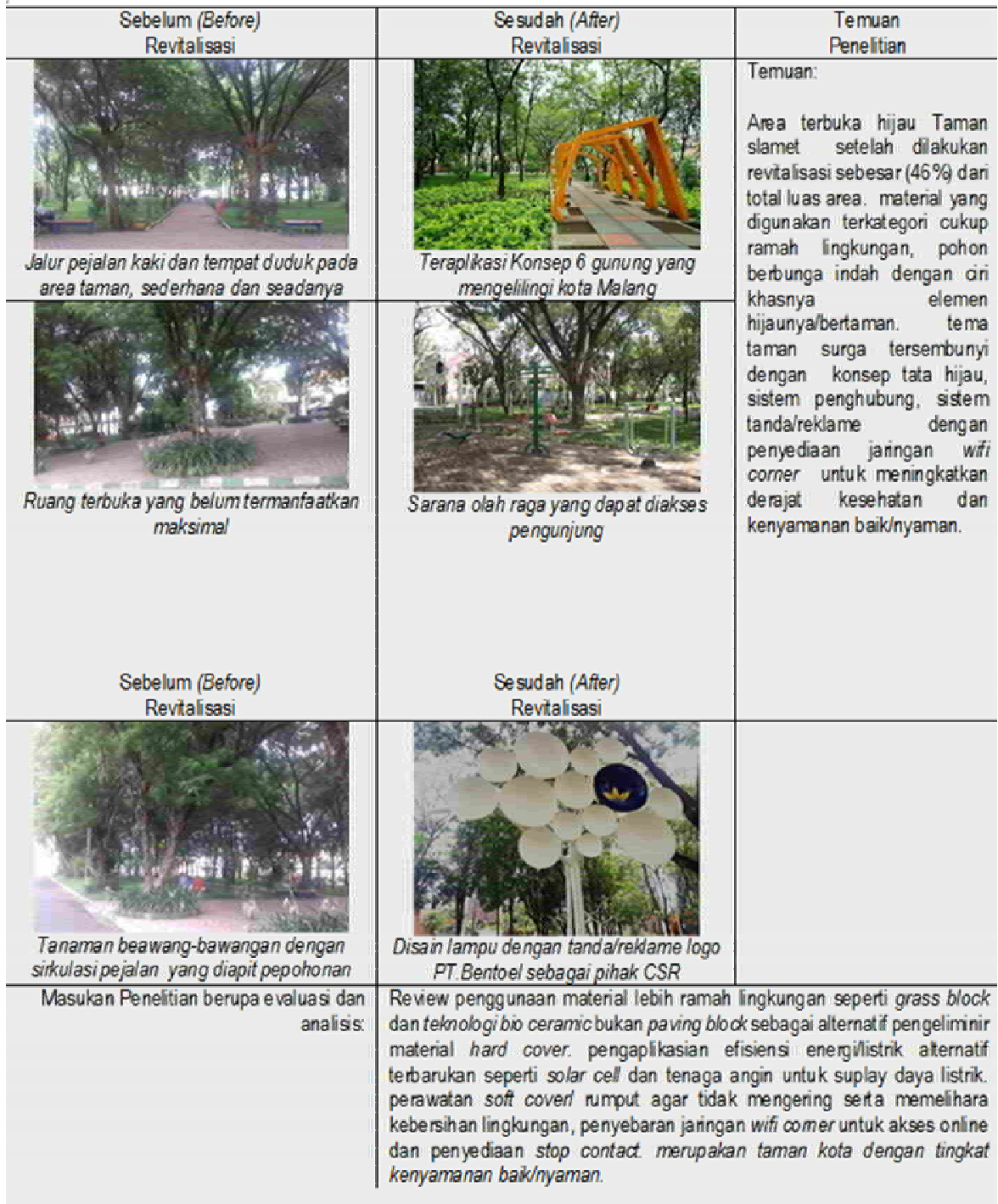

Sumber: Hasil Riset Peneliti (2018)

\section{Koridor Jalan Dan Pedestrian Dieng}

Koridor Jalan dan Pedestrian Dieng terletak di Jalan Dieng Kelurahan Gading Kasri Kecamatan Klojen Kota Malang. Ruang terbuka ini termasuk Sebagai RTH ruang koridor atau pergerakan linier, berupa jalur hijau jalan. Pemanfaatan RTH ini sebagai areal taman pasif, dalam wilayah hirarki ketetanggaan dan komuniti. Diapit oleh dua jalur jalan di kiri kananya dengan jalur pedestrian disampingnya serta ruang pulau ditengahnya. 
LOCAL WISDOM, Vol. 11 No. 1 Januari 2019

Local Wisdom Scientific Online Journal

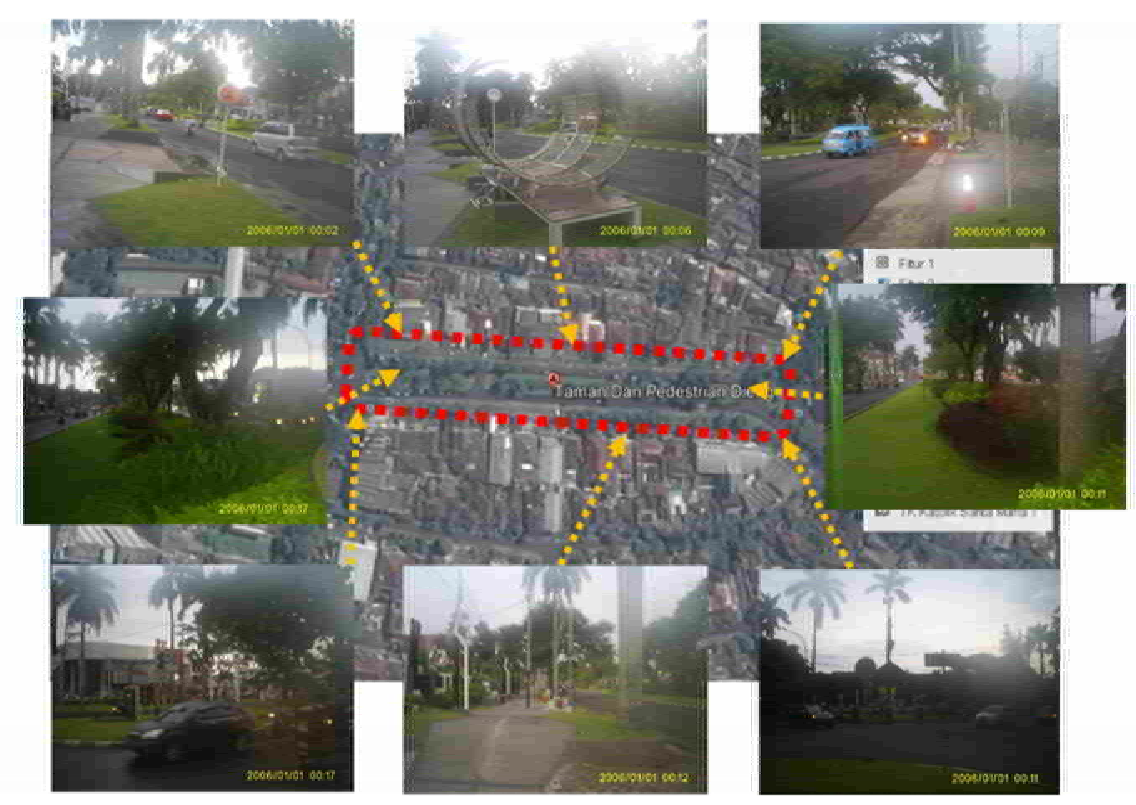

Gambar 12 Visualisasi Koridor Jalan dan Pedestrian Dieng Kota Malang

Sumber: (Google Earth Pro, diakses Kamis,07/12/ 2017 jam 11.24 dan Dokumentasi Peneliti 2018)

Sesuai dengan hasil observasi dan pengukuran dilapangan, didapatkanlah perhitungan berdasarkan Tabel 33 berupa Full Hard Space 55\%, terdapat alih fungsi atau penambahan bangunan eksisting Jalan Beraspal, pos polisi, trotoar, ruang duduk, plesteran serta lampu penerangan dengan material penutup Atap Dak beton (pos polisi) dan trotoar Beton Aci..Semi Hard Space 3\% dengan penambahan paving stone dan kanstin dengan material penutup beton, sedangkan Soft Space $42 \%$ berupa hamparan rumput hijau dengan varietas rumput gajah mini.

Tabel 6 Kajian Persentase Alih Fungsi dan Material Penutup pada Koridor Jalan dan Pedestrian Dieng Kota Malang

\begin{tabular}{|c|c|c|c|c|c|}
\hline No & $\begin{array}{l}\text { Nama Pengurangan } \\
\text { (Coverage) }\end{array}$ & $\begin{array}{l}\text { Luas } \\
\text { Ruang } \\
\text { (M2) }\end{array}$ & $\begin{array}{c}\text { Persen } \\
\text { tase } \\
(\%)\end{array}$ & $\begin{array}{l}\text { Alih Fungsil } \\
\text { Penambahan } \\
\text { Bangunan }\end{array}$ & $\begin{array}{l}\text { Penggunaan } \\
\text { Area Fungsil } \\
\text { Material } \\
\text { Penutup }\end{array}$ \\
\hline 1 & $\begin{array}{l}\text { Full Hard Space } \\
\text { 1. Jalan beraspal } \\
\text { 2. Pos Polisi, Trotoar, } \\
\text { Lampu taman. }\end{array}$ & $\begin{array}{l}3.844,06 \\
1.713,34\end{array}$ & & $\begin{array}{l}\text { Jalan eksisting } \\
\text { Trotoar }\end{array}$ & $\begin{array}{l}\text { Aspal } \\
\text { Beton Aci } \\
\text { Beton Dak }\end{array}$ \\
\hline & Jumlah I & $5.557,40$ & $55 \%$ & & \\
\hline II & $\begin{array}{l}\text { Semi Hard Space } \\
\text { Paving Stone }\end{array}$ & 309,93 & & $\begin{array}{l}\text { Paving dan } \\
\text { Kanstin }\end{array}$ & Beton \\
\hline & Jumlah II & 309,93 & $3 \%$ & & \\
\hline III & $\begin{array}{l}\text { Soft Space } \\
\text { Rumput }\end{array}$ & $4.229,41$ & & $\cdot$ & $\begin{array}{l}\text { Rumput Gajah } \\
\text { Mini }\end{array}$ \\
\hline & PedestrianJumlah III & 4.229,41 & $42 \%$ & & \\
\hline $\begin{array}{l}\text { Luas } \\
\text { Pede }\end{array}$ & $\begin{array}{l}\text { Keseluruhan Jalan dan } \\
\text { strian Dieng }\end{array}$ & $10.096,74$ & $100 \%$ & & \\
\hline
\end{tabular}

Sumber: Hasil Riset Peneliti (2018) 


\section{Kajian Persentase Ruang Terbuka Hijau pada Implementasi Revitalisasi Taman Kota Malang Juwito, Respati Wikantiyoso, Pindo Tutuko}

Hasil analisis Gambar 25 meperlihatkan material penutup (covering) pada Koridor Jalan dan Pedestrian Dieng yang terdiri dari ; warna merah (hard space), warna kuning (semi hard space) dan warna hijau (sofe space).

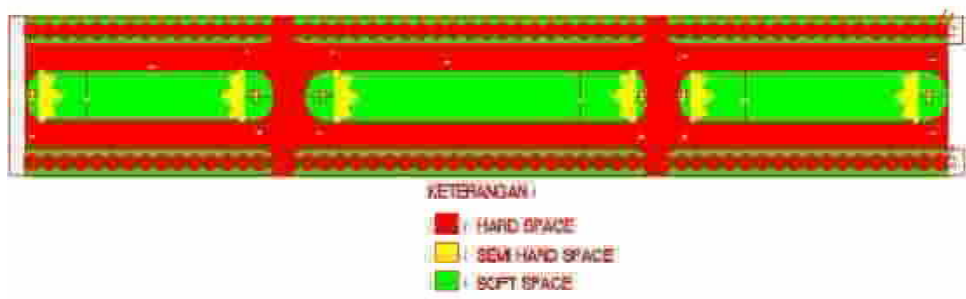

Gambar 13 Analisis Persentase Alih Fungsi dan Material Penutup pada Koridor Jalan dan Pedestrian Dieng

Skala 1:1000

Sumber: Hasil Riset Peneliti (2018)

Hasil analisis Pie Chart menunjukkan persentase material penutup (covering) pada Koridor Jalan dan Pedestrian Dieng yang terdiri dari ; warna merah hard space (55\%), warna kuning semi hard space (3\%) dan warna hijau sofe space ( $42 \%)$.

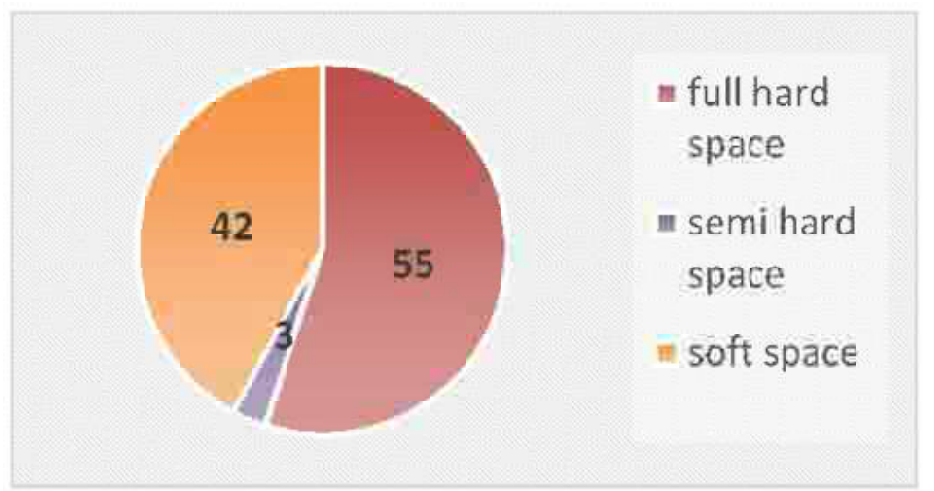

Pie Chart 3 Persentase Alih Fungsi dan Material Penutup pada Koridor Jalan dan Pedestrian Dieng Sumber: (Analisis Peneliti, 2018) 
LOCAL WISDOM, Vol. 11 No. 1 Januari 2019

Local Wisdom Scientific Online Journal

Tabel 7 Kondisi sebelum, sesudah, temuan penelitian dan masukan penelitian

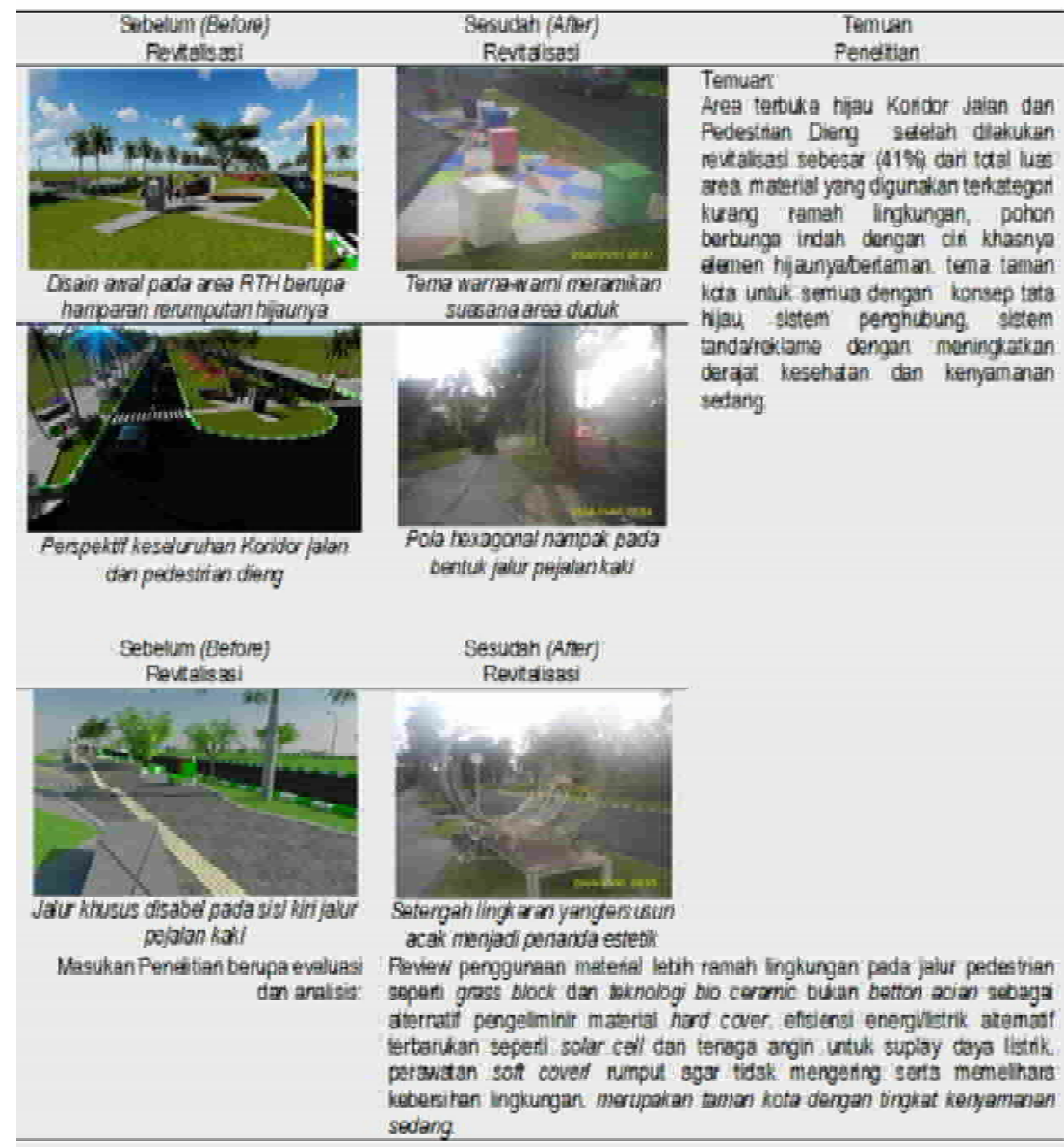

Sumber: Hasil Riset Peneliti (2018)

\section{Hutan Kota Malabar}

Hutan Kota Malabar terletak di Jalan Malabar Kelurahan Oro-oro Dowo Kecamatan Klojen Kota Malang. Dengan total luas area 16.178 M2. Awal mula nama Hutan Kota Malabar adalah 'Kebun Rodjo'. hal tersebut dikarenakan sebagai tempat bermain bola dan lempar lembing oleh anak-anak. Dalam wilayah hirarki kota dan wilayah sebagai RTH Makro yang "aktif". 


\section{Kajian Persentase Ruang Terbuka Hijau pada Implementasi Revitalisasi Taman Kota Malang Juwito, Respati Wikantiyoso, Pindo Tutuko}

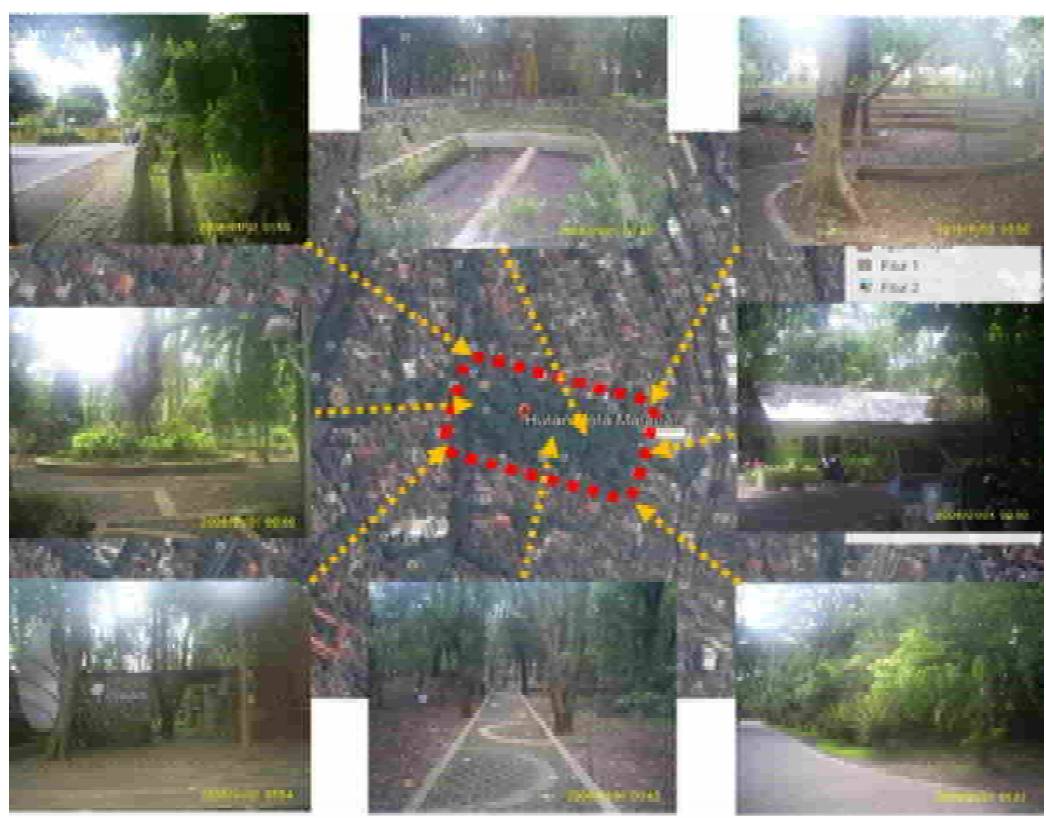

Gambar 14 Visualisasi Hutan Kota Malabar Kota Malang

Sumber: (Google Earth Pro, diakses Kamis,07/12/ 2017 jam 11.24 dan Dokumentasi Peneliti 2018)

Sesuai dengan hasil observasi dan pengukuran dilapangan, didapatkanlah perhitungan berdasarkan Tabel 47 berupa Full Hard Space 1\%, terdapat alih fungsi atau penambahan bangunan dinding Penahan kolam reservoir, Tower BTS dan batu terapi, jalan setapak, ruang duduk, serta lampu penerangan dengan material penutup pasabgan batu segi enam (reservoir) dan dinding penahan.Semi Hard Space 17\% dengan penambahan paving stone dan kanstin dengan material penutup beton, sedangkan Soft Space $82 \%$ berupa hamparan rumput liar dan tanah.

Tabel 8 Kajian Persentase Alih Fungsi dan Material Penutup pada Hutan Kota Malabar Kota Malang

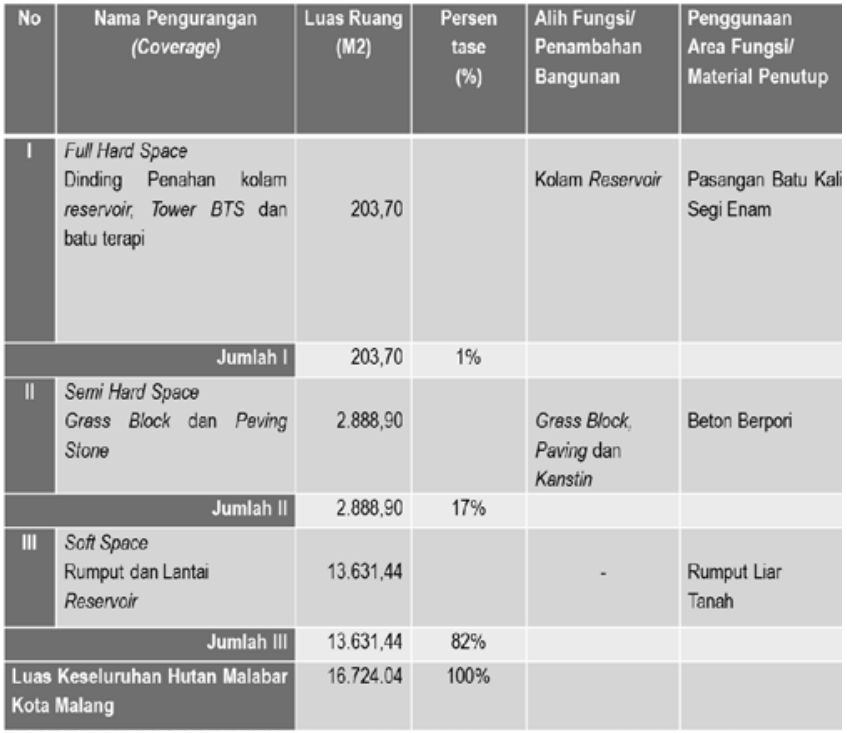

Sumber: Hasil Riset Peneliti (2018) 
Hasil analisis Gambar 27 meperlihatkan material penutup (covering) pada Hutan Kota Malabar yang terdiri dari; warna merah (hard space), warna kuning (semi hard space) dan warna hijau (sofe space).
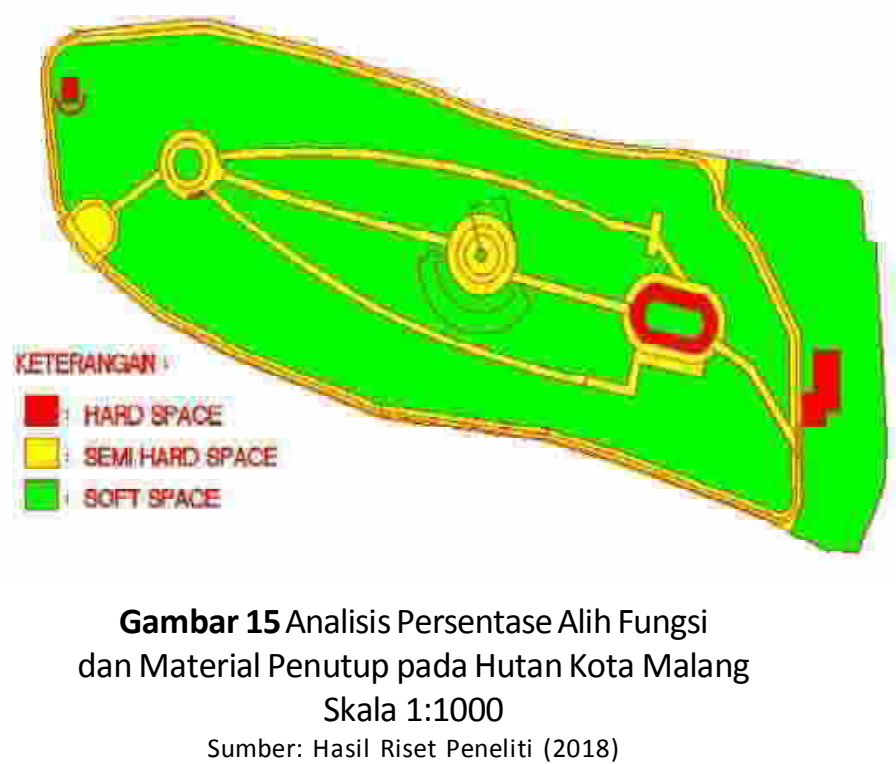

Hasil analisis Pie Chart menunjukkan persentase material penutup (covering) pada Hutan Kota Malabar yang terdiri dari; warna merah hard space (1\%), warna kuning semi hard space (17\%) dan warna hijau sofe space $(82 \%)$.

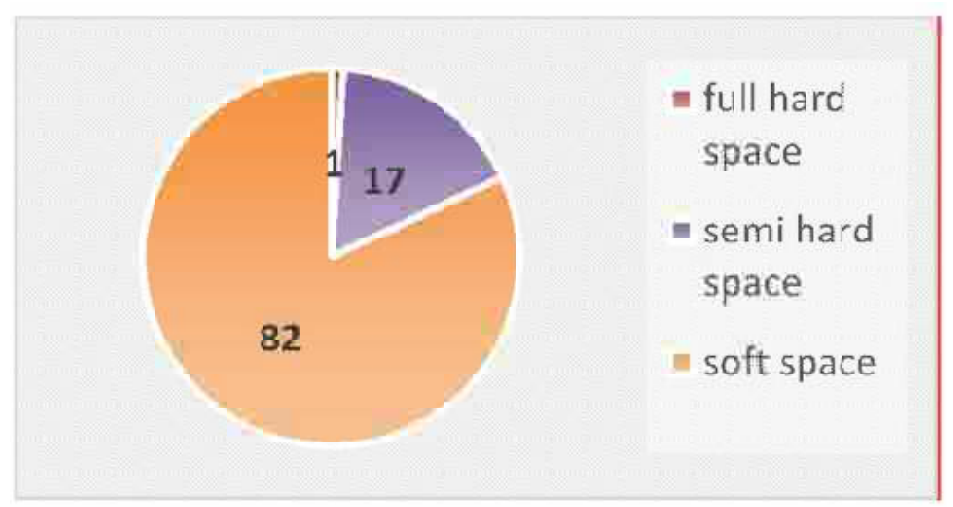

Pie Chart 4 Persentase Alih Fungsi dan Material Penutup pada Hutan Kota Malang Sumber: (Analisis Peneliti, 2018) 
Tabel 9 Kondisi sebelum, sesudah, temuan penelitian dan masukan penelitian

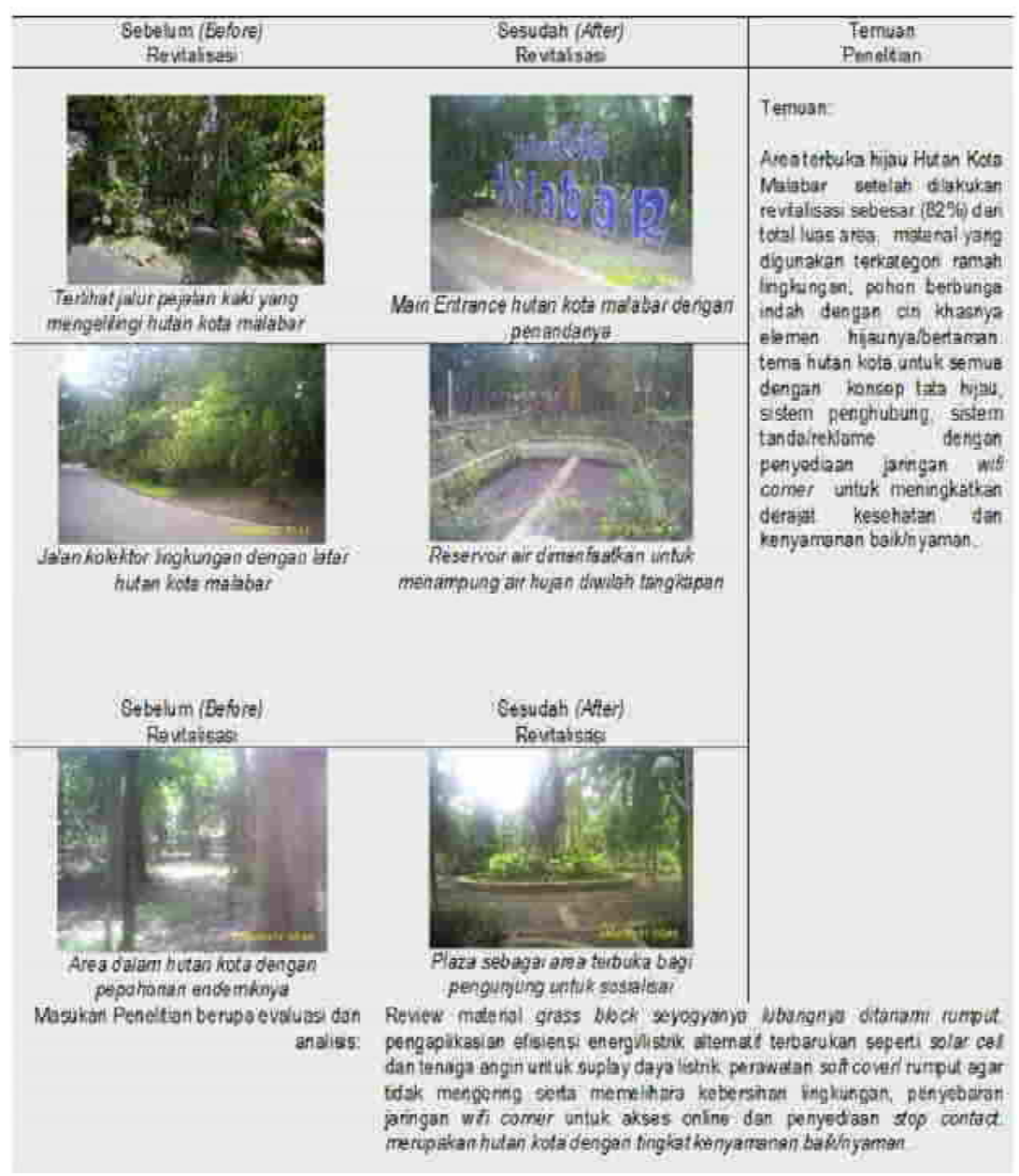

Sumber: Hasil Riset Peneliti (2018)

\section{Karakteristik Objek Kajian Berdasarkan Program Revitalisasi RTH}

1. Taman Alun-Alun Merdeka Kota Malang

Taman Alun-alun Merdeka Kota Malang merupakan RTH strategis berdasar hirarkinya berfungsi sebagai RTH kota dan wilayah sebagai taman aktif. Area terbuka hijau Alun-alun setelah dilakukan revitalisasi sebesar $(76 \%)$ dari total luas area. Material yang digunakan terkategori cukup ramah lingkungan, merupakan taman kota dengan tingkat kenyamanan baik/nyaman serta dapat diakses 24 jam oleh pengunjung. Penggunaan material lebih ramah lingkungan seperti grass block dan teknologi bio ceramic bukan paving block (eksiting) sebagai alternatif pengeliminir material hard cover. Pengaplikasian efisiensi energi/listrik alternatif terbarukan seperti solar cell dan tenaga angin untuk suplay daya listrik obyek. Perawatan soft cover/ rumput sebagai penciri taman Alun-alun Merdeka ini agar tidak mengering serta senantiasa merawat dan menjaga kebersihan lingkunganya. 
Penyebaran jaringan wifi corner untuk akses online dengan penyediaan stop contact dengan mengusung Tema: Taman Kota Untuk Semuanya.

2. Taman Slamet

Taman Slamet tergolong Taman Ruang pulau atau tempat pemberhentian sementara. penggunaan RTH ini sebagai areal taman, sosialisasi, releksasi dan rekreasi. dalam wilayah hirarki ketetanggaan dan komuniti sebagai taman aktif. Area terbuka hijau Taman slamet setelah dilakukan revitalisasi sebesar (46\%) dari total luas area. Material yang digunakan terkategori cukup ramah lingkungan, pohon berbunga indah dengan ciri khasnya elemen hijaunya/bertaman. Pengaplikasian efisiensi energi/listrik alternatif terbarukan seperti solar cell dan tenaga angin untuk suplay daya listrik obyek. Penyebaran jaringan wifi corner untuk akses online dan penyediaan stop contact. Merupakan Taman yang mengakomodasi kegiatan ekonomi informal dan formal (local economic development) dengan fasilitas tempat duduk-duduknya. Taman Slamet merupakan taman kota dengan tingkat kenyamanan baik/nyaman dengan disertai penambahan fasilitas toilet. Mengusung Tema: Surga Tersembunyi Di Tengah Kesibukan Kota (Hidden Paradise).

3. Koridor Jalan Dan Pedestrian Dieng

Koridor Jalan dan Pedestrian Dieng merupakan RTH ruang koridor atau pergerakan linier, berupa jalur hijau jalan. Pemanfaatan RTH ini sebagai areal taman pasif, dalam wilayah hirarki ketetanggaan dan komuniti. Area terbuka hijau Koridor Jalan dan Pedestrian Dieng setelah dilakukan revitalisasi sebesar (41\%) dari total luas area. Material yang digunakan terkategori kurang ramah lingkungan. Penggunaan material lebih ramah lingkungan pada jalur pedestrian seperti grass block dan teknologi bio ceramic bukan betton acian (eksiting) sebagai alternatif pengeliminir material hard cover.Jalur pedestrian yang naik turun disertai teriknya sinar matahari yang tidak terhalau vegetasi terasa kurang ramah bagi pejalan kaki, dengan ciri belum terintegrasinya polisi taman pada RTH ini. Merupakan taman kota dengan tingkat kenyamanan sedang dengan mengusung Tema: Taman Hexagonal.

4. Hutan Kota Malabar

Dalam wilayah hirarki kota dan wilayah sebagai RTH Makro yang pasif menjadi "aktif". Area terbuka hijau Hutan Kota Malabar setelah dilakukan revitalisasi sebesar (82\%) dari total luas area. material yang digunakan terkategori ramah lingkungan, pohon-pohon besar dengan keheterogenan flora dan faunanya yang terjaga dan terpelihara menjadi pencirinya sebagai hutan hujan tropis. Hutan kota Malabar ini merupakan satu-satunya RTH yang dibatasi jam kunjunganya waktu pagisore hari. Penggunaan material grass block seyogyanya lubangnya ditanami rumput. pengaplikasian efisiensi energi/listrik alternatif terbarukan seperti solar cell dan tenaga angin untuk suplay daya listrik obyek. Penyebaran jaringan wifi corner untuk akses online dan penyediaan stop contact. Merupakan hutan kota dengan tingkat kenyamanan baik/nyaman. Dengan mengusung Tema: Sensasi Hutan Di Tengah Kota.

\section{Kesimpulan}

Kegiatan Revitalisasi RTH menimbulkan dampak dan impact berupa (1) Alih fungsi atau penambahan bangunan dan; (2) Penggunaan area fungsional/bahan atau material penutup (cover). Pengurangan RTH ini secara fungsional berupa pengaplikasian bahan (1) Soft Space dan; (2) Hard Space. 
Pemilihan material yang tepat dengan tema dan ciri RTH dengan teknologi yang berkesinambungan menjadi satu kesatuan yang terintegrasi dengan perbaikan kualitas dan kuantitas lingkungan secara lestari.

1. Dampak negatif Revitalisasi RTH pada ke 4 (empat) objek penelitian diantaranya:

Penambahan bangunan baru berupa fasilitas umum dan sosial yang tidak tepat dan permanen seperti (bangunan pos polisi, pos polisi taman, area duduk (sitting area) yang masif tower BTS,TPS serta gedung PKD).

Berkuranya Area Terbuka Hijau dengan Pengaplikasian material Ground covering yang tidak ramah lingkungan. pemilihan dan keputusan disain perencanaan dan perancangan yang tidak tepat dengan pengaplikasian material hard cover sehingga mengurangi luas area hijau yang sudah ada. aplikasi disain dengan mengunakan plesteran beton masif epoxy dan paving block dan bukan grass block. Kalaupun material "grass block" tidak difungsikan maksimal (rongganya tidak ditanami rumput).

2. Impact positif Revitalisasi RTH pada objek penelitian diantaranya:

Meningkatkan citra kawasan dan kondisi visual kawasan dengan memperhatikan konteks lingkungan. Dapat juga mengakomodasi kegiatan ekonomi informal dan formal (local economic development). Menjadikan lingkungan menarik (interesting) dan meningkatkan dinamika dan kehidupan sosial masyarakat/warga (public realms). Meningkatkan fungsi ekologis, sosial budaya, arsitektur dan ekonomi RTH, serta mendukung peran masyarakat dalam wujud mensukseskan program pengembangan kota hijau (P2KH)

\section{Rekomendasi}

Kegiatan Revitalisasi RTH dengan mepertimbangkan ketepatan disain perencanaan dan perancangan berupa penambahan bangunan baru fasilitas umum dan fasilitas sosial yang baik. Pemilihan material Ground Covering yang sangat ramah lingkungan sebagai alternatif pengeliminir kekuranganya.

Pengaplikasian efisiensi energi/listrik alternatif untuk kebutuhan energi RTH baik itu Cell surya, tenaga angin maupun energi terbarukan lainya. Mengaplikasikan konsep tata hijau, sistem penghubung, sistem tanda/reklame dengan penyediaan jaringan wifi corner dan penyediaan stop contact untuk meningkatkan kemudahan akses derajat kesehatan dan kenyamanan pengunjung

Mengingat 63\% RTH Kota Malang terpasok dari RTH Tepi Sungai, maka untuk memberikan pensubtitusian pengurangan RTH hasil Revitalisasi, seyogyanya diatur kewenanganya dalam berkontribusi pengolahan lahan pontensial tersebut. seberapa \% penguranganya dikonversikaan dengan memberikan pengelolaan/intervensi fisik RTH tersebut dengan panduan dan pengawasan yang ketat.

Mengingat penelitian ini membatasi 4 dari 17 objek kajian RTH (Taman kota, Hutan kota dan Taman Lingkungan serta koridor jalan dan pedestrian) maka diperlukan penelitian lanjutan yang lebih besar objeknya (RTH Lapangan,Pemakaman,Tepi Sungai,Jalur Kereta Api dan Sutet) yang lebih mendetail. 


\section{LOCAL WISDOM, Vol. 11 No. 1 Januari 2019}

Local Wisdom Scientific Online Journal

\section{Daftar Pustaka}

Alabi, M. O. (2009). Revitalizing urban public open spaces, through, vegetative enclaves in Lokoja, Nigeria. Journal of Geography and Regional Planning, 2(3), 51-54.

BARENLITBANG. Rencana Pembangunan Jangka Menengah Daerah Kota Malang 2013-2018 (2014). Malang. Retrieved from http:// barenlitbang.malangkota.go.id/dokumen-dan-produk-hukum/r-p-j-m-d/

BIROHUKUM, P. Pedoman revitalisasi kawasan PERMENPU No.18 Tahun 2011 (2011). Makasar. Retrieved from http://birohukum.pu.go.id/pustaka/arsip_makalah/17.pdf

DISPERKIM. (2017). Revitalisasi Taman Jalan Dieng - Dinas Perumahan dan Kawasan Permukiman Kota Malang. Malang. Retrieved from http://dpkp.malangkota.go.id/2017/01/revitalisasi-taman-jalan-dieng/

Ekaputra YD, S. M. (2012). Implikasi Program Pengembangan Kota Hijau P2KH terhadap Pemenuhan Luasan RTH Perkotaan, (2000), 27-32.

Hamidah, N., Garib, T. W., \& Santoso, M. (2015). Pengelolaan Kawasan Ruang Hijau di DAS Kahayan Kota Palangka Raya. Perspektif Arsitektur, 10(1), 13-25.

Imansari, N., \& Khadiyanta, P. (2015). Penyediaan Hutan Kota dan Taman Kota sebagai Ruang Terbuka Hijau ( RTH ) Publik Menurut Preferensi Masyarakat di Kawasan Pusat Kota Tangerang, (3), 101-110.

Ingerid L. Moniaga(1), E. D. T. (2015). Pengembangan RTH Kota Berbasis Infrastruktur Hijau dan Tata Ruang. Iplbi, (1), 27-32.

KEMENPUPERA. (2016). Manual Kegiatan Program Pengembangan Kota Hijau 2016.

Majawati. (2016). Hutan Kota Malabar, Sensasi Hutan di Tengah Kota oleh Majawati - Kompasiana. Retrieved from https:/ / www.kompasiana.com/majawati/hutan-kota-malabar-sensasi-hutan-di-tengahkota_5771067c0f9373a007fa7395

Ninno, E. (2017a). Alun Alun Kota Malang - Taman Kota Untuk Semuanya _ nnoart. Retrieved from http:// www.nnoart.com/2017/04/alun-alun-kota-malang-taman-kota-untuk-semuanya.html

Ninno, E. (2017b). Taman Slamet Malang - Surga Tersembunyi di Tengah Kesibukan Kota _ nnoart. Malang. Retrieved from http://www.nnoart.com/2016/12/taman-slamet-malang-surga-tersembunyi-tengah-kota.html

Nugroho, D. S., \& Syaodih, E. (2013). Strategi Peningkatan Kualitas Empat Atribut Green City di Kecamatan Bandung Wetan Kota Bandung, 37-47.

PERMENDAGRI NO.01. Peraturan Menteri Dalam Negeri Nomor 1 Tahun 2007 Tentang Penataan Ruang Terbuka Hijau Kawasan Perkotaan (2007).

PERMENPU NO.05. Pedoman Penyediaan dan Pemanfaatan RTH di Kawasan Perkotaan (2008).

Rahmy, W. A., Faisal, B., \& Soeriaatmadja, A. R. (2012). Kebutuhan Ruang Terbuka Hijau Kota pada Kawasan Padat, Studi Kasus di Wilayah Tegallega,Bandung. Lingkungan Binaan Indonesia, 1(1), 27-38.

Rawung, F. (2015). Efektivitas Ruang Terbuka Hijau (RTH) dalam Mereduksi Emisi Gas Rumah Kaca (GRK) di Kawasan Perkotaan Boroko. Media Matrasain, 12(2), 17-32. Retrieved from http://ejournal.unsrat.ac.id/ index.php/jmm/article/view/9204

Subadyo, A. (2011). Persepsi dan Preferensi Masyarakat Terhadap Community Park ( Studi Kasus di Perumahan Kota Araya Malang ), 1-16. 


\section{Kajian Persentase Ruang Terbuka Hijau pada Implementasi Revitalisasi Taman Kota Malang \\ Juwito, Respati Wikantiyoso, Pindo Tutuko}

Sudarwani, M. M. (2015). Kompetensi Arsitek Dalam Mendukung Terwujudnya Kota Hijau, (1), 12.

Suhartono T. (2011). Modal Sosial dalam Pemanfaatan Ruang Terbuka Hijau (RTH) di lingkungan Kota Malang (Studi fenomenologis diperumnas Sawojajar kec.kedungkandang Kota Malang). Merdeka Malang.

Tanan, N., \& Suprayoga, G. B. (2015). Fasilitas Pejalan Kaki Dalam Mendukung Program Pengembangan Kota Hijau, $1(1), 17-28$.

UNDANG-UNDANG NO.26, 2007. UU No. 26 Tahun 2007 Tentang Penataan Ruang, Pemerintah Republik Indonesia § (2007). Retrieved from www.pu.go.id

Wikantiyoso, R. (2005). Paradigma Perencanaan dan Perancangan Kota (Edisi Kedua) (2nd ed., pp. 49-57). Malang: Group Konservasi Arsitektur dan Kota.

Wikantiyoso, R. (2010). Pemanfaatan dan Perancangan Kawasan Tepi Air Sungai Terpadu dan Berkelanjutan sebagai Subtitusi Pengurangan RTH Kota, p. 12.

Wikantiyoso, R. (2017). The role of CSR in the Revitalization of City Open Space for better sustainable urban development by Respati Wikantiyoso _ Research Project on ResearchGate. Retrieved from https:// www.researchgate.net/ project/The-role-of-CSR-in-the-Revitalization-of-City-Open-Space-for-better-sustainable-urban-development

Wikantiyoso, R., \& Tutuko, P. (2013). Planning Review: Green City Design Approach for Global Warming Anticipatory Surabaya's Development Plan. International Review for Spatial Planning and Sustainable Development, 1(3), 4-18. https://doi.org/http://dx.doi.org/10.14246/irspsd.1.3_4 